\title{
Remigration Intentions and Migrants' Behavior
}

\author{
Bastien Chabé-Ferret $^{\mathrm{a}} \quad$ Joël Machado $^{\mathrm{b}} \quad$ Jackline Wahba $^{\mathrm{c}}$
}

\begin{abstract}
Using a unique French dataset, we analyze the relationship between remigration intentions and several immigrants' behaviors in the host and origin countries addressing the potential endogeneity of remigration intentions. We also investigate the potential trade-off and complementarities between various immigrants' investment behaviors. We find that temporary migrants are more likely to invest in the country of origin but less likely to invest in the host country. Moreover, our results suggest a trade-off between immigrants' investment in the home and in the host country.
\end{abstract}

Keywords: Temporary migration, intention to leave, return intention, remittances.

JEL codes: F22, F24, D14.

\section{Acknowledgement}

We thank two anonymous referees for constructive comments. We are also grateful to Simone Bertoli, Michel Beine, Frédéric Docquier, Corrado Giulietti, Majlinda Joxhe, Sekou

\footnotetext{
${ }^{a}$ Corresponding author. FNRS and IRES, Université catholique de Louvain - Place Montesquieu, 3, bte L2.06.01 B-1348 Louvain-la-Neuve, Belgium. IZA, Bonn. E-mail: bastien.chabe-ferret@uclouvain.be

${ }^{\mathrm{b}}$ Luxembourg Institute of Socio-Economic Research (LISER), 11, Porte des Sciences, L-4366 Esch-sur-Alzette, Luxembourg. Email: joel.machado@liser.lu

${ }^{c}$ Economics Division, University of Southampton - SO17 1BJ, Southampton, UK. Email: j.wahba@soton.ac.uk
} 
Keita, Sebastian Otten and participants at the LISER seminar, CORE Brown Bag seminar, ESPE2014 Braga, GDRI Workshop on international migration, the 2nd Workshop on the economics of migration in Frankfurt and the CEMIR Junior Economist Workshop on Migration Research 2017 for helpful suggestions. The first author acknowledges financial support from the Belgian French-speaking community (ARC convention 09-14018 on "Sustainability" and 15/19-063 on "Family transformations".), the FNRS and European Research Council (ERC Stg Grant DU 283953), the second from the Fonds National de la Recherche, Luxembourg (9037210). The usual disclaimers apply.

\section{Introduction}

Temporary migration is an important facet of migratory movements. ${ }^{1}$ Faced with growing opposition to immigration, destination countries in Western Europe and the US have recently relied on more selective and temporally constrained migration schemes. These schemes were designed in the belief that the hosting society could benefit from the immigrant labor force (younger, working-age individuals contributing to the welfare state) while reducing the potential costs associated with immigration (in particular by reducing the need for cultural assimilation and limiting access to some welfare transfers). Yet, not enough is known about how temporary migration and in particular remigration intentions affect immigrants' behavior.

Remigration intentions might impact whether immigrants invest in the host country both in terms of specific human capital and physical capital. On the one hand, immigrants who plan to leave might have little incentive to assimilate or to invest in host-country-specific human capital such as language (Dustmann, 1999). They might also be less likely to invest in physical capital, such as housing, because of the limited asset-return period. On the other hand, temporary migrants might invest in language skills if the returns to human capital accumulated abroad are high (Dustmann, 1997). Moreover, investment in the host country might be the ideal channel to accumulate savings before a potential leave.

Thus, the implications of temporary migration might not be straightforward and require empirical evidence. Although remigration intentions do not always materialize in actual leave or out-migration, this is not a concern for us since our interest is in how current remigration intentions impact current behaviour as opposed to future behaviour. As Dustmann and Görlach (2016)

\footnotetext{
${ }^{1}$ See Dustmann and Görlach (2016) for a recent survey of the literature.
} 
point out, observing completed migration spells would not be useful, since shocks are likely to affect migrants' remigration plans during the migration spell.

We study the relationship between migrant's intention to leave the host country and several behavioral decisions. We focus on the case of France where immigration assimilation has been under scrutiny recently. We use a unique individual level household survey data, called "Trajectoires et origines", collected in France in 2008-09. This rich data includes information on immigrants' financial, human and social capital investment decisions both in the host (France) and home country. In this representative sample of the migrant population in France, a majority of those intending to leave are planning to return to their country of origin. ${ }^{2}$

We account for the potential endogeneity of remigration intentions and observed outcomes using the intention to be buried outside France and the perception of discrimination in France as exclusion restrictions. In addition, we investigate the potential trade-off or complementarity between various immigrants' investment decisions. Indeed, whether immigrants' investment decisions at home and at host move in the same direction or compete with one another is unknown. For example, previous studies generally find that temporary migrants are more likely to remit compared to permanent ones. ${ }^{3}$ At the same time, they are also more likely than permanent migrants to save for their own future consumption or investment, which could be done at the expense of investment in their origin country.

This paper aims at contributing to a small literature on the effect of temporary migration plans on behavior in the host and home country. Our approach allows an improvement on three fronts. First, unlike previous studies, we study a number of immigrants' decisions, rather than one outcome in

\footnotetext{
${ }^{2}$ Return migration from Western European countries has been documented to be substantial. See for example, Bijwaard (2010) on return migration from the Netherlands.

${ }^{3}$ These monetary transfers might increase the recipients' consumption or serve to prepare the migrant's return (see e.g. Amuedo-Dorantes and Pozo, 2006). Some experiments on directed giving have shown that immigrants like to have some control over their monetary transfers (Batista et al. 2015, Torero and Viceisza, 2015). Labeling remittances as intended for a specific purpose, such as children' education, might also increase the propensity to remit of migrants (De Arcangelis et al., 2015). Finally, remittances can also be perceived as a way of self-insurance for migrants (Batista and Umblijs, 2016). The information provided in our survey data focuses on financial transactions only and does not stipulate the motives of the transfer or whether a specific expense is intended by the migrant.
} 
isolation, in order to build a more complete picture of immigrants' behavior.

A second source of improvement comes from our treatment of the potential endogeneity of remigration intentions. Indeed, the desire to leave France and investment decisions of migrants may be caused by unobserved characteristics or the causation may actually run in the opposite direction. We rely on the variation in remigration intentions provided by instrumental variables that are not likely to be linked to the outcomes in any other way than through remigration intentions. In particular, we use intention to be buried abroad for outcomes related to France and opinion about the extent of discrimination in France for outcomes directed to the origin country. ${ }^{4}$

Finally, we explicitly take into account the potential trade-offs and/or complementarity when estimating the investment decisions on a large set of choices. Most previous studies either focused on a sole outcome or when examining two outcomes, such as remittances and savings for example, ignored the correlation between those decisions. We examine the potential trade-offs and complementarity between not only physical investment decisions, but also human capital investment decisions and non-monetary decisions. In addition, we repeat our analysis on the subsample of immigrants from Africa, the main region of origin of immigrants in France.

We find that migrants who intend to leave are more likely to invest in their home country and less likely to invest in host-specific assets. We also uncover that remigration intentions lead to a substitution between investment at home and at host (at least at the level of the extensive margin): temporary migrants are more likely to invest at home while simultaneously being less likely to invest in France. Focusing on African immigrants, we find that remigration intentions affect their monetary investment decisions significantly more than for the average immigrant in the full sample. In contrast to what we find for the full sample, intention to leave does not significantly reduce African migrants' probability to invest in France while it does increase their probability to invest at origin when both investments are considered jointly.

This paper has important policy implications. First, if the duration of the migration spell impacts immigrants' investment behavior in the host country, this should be better accounted for in the design of migration policies. For instance, if host countries want to foster the integration of immigrants, it

\footnotetext{
${ }^{4}$ The perceived level of discrimination one lives in has indeed been documented as a push factor in the emigration decision. See for instance Ruyssen \& Salomone (2015).
} 
is important to provide the right incentives by securing certainty on the duration of stay. Repeated temporary visas might reduce the expected gains of this type of investment for the migrant. Secondly, our results raise a concern about the implications of temporary migration schemes as they are likely to lead to lower investments by migrants in the host country- an issue that needs to be redressed in particular as far as language and assimilation are concerned. Thirdly, however, temporary migrants and those planning to leave are a potential channel through which human and financial resources flow back to home countries. These links could help to improve financial and economic (among others) relations between host and home countries.

The structure of the paper is as follows: in Section 2 we discuss the related literature. In Section 3 we provide some background information and discuss the data and our sample. In Section 4 we introduce our estimation strategies and we present our estimation results and robustness checks in Section 5. Section 6 concludes.

\section{Previous Literature}

There exists a small theoretical literature which provides several explanations for the determinants of temporary migration and optimal migration abroad. On the one hand, temporary migration might be planned and part of an optimal decision-making process based on the maximization of the total lifetime utility. ${ }^{5}$ In this set up, preferences for the home country or differences in relative prices lead to a return even though income differentials persist (see Djajic and Milbourne, 1988). Temporary migration might also serve to accumulate savings, helping migrants to overcome budget constraints in order to invest in the country of origin (Djajic 2010; Mesnard 2004). Higher returns in the origin country to human capital acquired in the host country can be an additional motive for temporary migration (Dustmann, 1997). However, income uncertainty in the host country might also imply higher remittances by generating a higher likelihood of return migration (Delpierre and Verheyden, 2014). On the other hand, remigration can be unplanned and the result of failure either due to imperfect information about the host country in terms of labor market prospects or cost of living or the inability to fulfil the migration plans in terms of target savings (see e.g. Borjas and

\footnotetext{
${ }^{5}$ See for example, Djajic (1989). Dustmann and Görlach (2016) provide a comprehensive review of the theoretical and empirical literature on temporary migration.
} 
Bratsberg, 1996).

This paper focuses on the effects of temporary migration on immigrants' behavior. The impact of temporary migration on remittances and transfers to the country of origin has been one important question addressed in this literature. For example, Dustmann and Mestres (2010) examine the remittance behavior of immigrants and how it relates to temporary versus permanent migration plans in Germany. They find that changes in remigration intentions are related to large changes in remittance flows. Merkle and Zimmermann (1992) also find that guest-workers' remigration plans are an important determinant of remittances but their results are however less clear cut for savings held in Germany. Bauer and Sinning (2011) instead examine the relative savings position of migrant households in West Germany paying particular attention to differences between temporary and permanent migrants. If remittances are treated as savings, migrants who intend to return to their home country save significantly more than comparable natives.

Another focus, yet not as common as remittances, has been that related to investment in human capital measured as language proficiency. Dustmann (1999) explores the effects of return migration on investment in the host country's language and finds that permanent migrants have a 10 percent higher probability to be fluent in German than temporary migrants. Whether those results hold in a country like France, whose national language is used in some of the countries of origin, is interesting to test.

Those studies do not consider the potential trade-off between remittances sent back home and saving/investment by the immigrant back home. In a recent study, Wolff (2015) analyzes the impact of return decisions of foreignborn retired individuals in France on remittances. Treating return intentions as exogenous, he finds that they increase the probability of remitting by more than 10 percentage points. The amount remitted is almost twice as high for temporary migrants. Finally, he finds a positive correlation between personal savings and remittances to origin country and between personal savings and transfers to relatives living in France. Conversely, remittances to origin country and family transfers in France tend to substitute each other. It is important to note though that the behaviour of retired individuals may be different from that of working age migrants, who are the focus here. Finally, De Arcangelis and Joxhe (2015) analyze saving and remitting behavior on a sample from the British Household Panel Survey. They find that temporary migrants save less and remit more than permanent ones. However, they rely on a noisy measure of remittances namely "giving money outside the 
household." Our paper, unlike those two papers, examines several outcomes, controlling for the endogeneity and tests for the potential trade-offs between home and host outcomes.

In the next sections, we discuss our data and empirical strategy to study the relationship between remigration intentions and immigrants' behavior in France.

\section{Data}

This section describes the data and provides some descriptive statistics on the sample used. The analysis is based on the French dataset "Trajectoires et origines" released by Ined-Insee in 2009. This large survey was conducted among a representative sample of French metropolitan households of working age between September 2008 and February 2009. Respondents can be classified in several subgroups: French, foreign-born or born in French Overseas Territories ("Département et région d'outre-mer", hereafter DOM) and the descendants of the respective categories born in France.

The survey sample consists of 21,761 observations and is representative of all individuals born after 1958 (although some origin countries are overrepresented among first- and second-generation immigrants). The survey explores the household's migratory background, social, educational and economic environment. It also includes questions on religious and linguistic transmission and perception of discrimination. Moreover, it allows exploring information on behavior relative to the origin country: does the migrant send remittances, finance a project at origin or participate in the political elections. Although we do not have a panel, our rich data set enable us to observe heterogeneous behavior of immigrants at different stages of their migration spells.

In this study, we focus on the behavioral differences among first-generation migrants who state a desire to leave France versus those who do not. Our interest lies in both host and origin country outcomes. This leaves a sample of 9,168 observations (Table 1). Among these, $7.8 \%$ were born in a DOM and $92.2 \%$ are foreign born. $15.7 \%$ of migrants (or 1,438 respondents) in the sample stated a desire to leave France, while $24.9 \%$ answered the survey question with "maybe". A majority of migrants (over 53.7\%) stated a desire to remain in France while 5.7\% replied "don't know". In our benchmark specification, we contrast those that explicitly state a desire to leave, 
the temporary migrants, with the remainder, or permanent migrants ("Yes" versus the rest). We check later the robustness of this definition. ${ }^{6}$

\subsection{Differences between temporary and permanent migrants}

INSERT Table $1+2$ : Descriptive Stats

Tables 1 and 2 summarize the descriptive statistics for the full sample, permanent and temporary migrants. As shown in Table 1, temporary migrants (i.e. those who state a desire to leave) differ in their characteristics from permanent migrants (i.e. those who do not state a desire to leave) along several dimensions. Temporary migrants are on average younger than permanent migrants at the time of the survey whereas they were not significantly younger upon arrival. Hence, they have, on average, spent slightly less time in France. ${ }^{7}$ About $65.1 \%$ of temporary migrants have a parent (father and/or mother) at origin while only $52.6 \%$ of permanent migrants do. Permanent migrants are also less likely to have a child living outside France.

As shown in Table 2, temporary migrants live proportionally less often with a partner and have slightly more often a partner abroad. They tend to be more educated than permanent migrants and are more concentrated in big agglomerations. The fraction of employed is slightly higher among temporary migrants while unemployment and inactivity are lower. They are more likely to be wage earners and slightly less likely to be self-employed. The fraction of students is also higher among them.

Examining the type of visa at arrival, unsurprisingly, the fraction of student visas is higher among temporary migrants while that of respondents who benefited from family reunion programs is lower. ${ }^{8}$ Asylum seekers make up $5.5 \%$ of the temporary migrants and $11.5 \%$ of permanent. $26.7 \%$ of tem-

\footnotetext{
${ }^{6}$ In our main set of estimations, temporary migrants are all the individuals that state a desire to leave France. Among these, 1082 (or 75\%) explicitly state their partner's or their own country of origin as their intended destination. Among the 382 individuals who mention a third country, the prevailing preferred destinations are North America (100 respondents) and the United Kingdom (37 respondents). We check the robustness of our results by focusing on return migration exclusively in Section 5.3.

${ }^{7}$ Note that we control for age at arrival and age at the time of survey which implicitly provides the duration of the migration spell (under the assumption that it was continuous).

${ }^{8}$ Although the legal status of immigrants can influence their intended duration of stay (see Coniglio et al. 2009, 2010) the data that we use does not allow us to control for illegal entry. These immigrants, if any, would be regrouped in the visa category "Other".
} 
porary migrants have a legal visa waiver (i.e. individuals from the Schengen area exempted from applying for a visa).

Focusing on the immigrants' investment behavior, about $19.9 \%$ of temporary migrants regularly remit (send money to relatives in their origin country) compared to $14.1 \%$ among permanent migrants. Temporary migrants are more likely to finance projects in their country of origin and own a house at origin $(30.3 \%$ versus $17.2 \%)$. They are however less likely to own a house in France (28.4\% versus $41.7 \%$ ). Temporary migrants are also more interested in the politics of their country of origin and more likely to have voted in an election related to the origin country.

Temporary migrants state a weaker improvement in French language between their date of arrival and the moment of the survey (46.5\% against $60.6 \%$ among permanent migrants). This is partly due to their apparently stronger French knowledge upon arrival. At the time of the survey, temporary migrants still seem to be more proficient in the French language than permanent migrants.

As shown in Tables 1 and 2, permanent and temporary migrants are statistically different along most observable characteristics (except for gender and age at arrival) and behavioral choices. They are more likely to have financial ties with their origin country and less likely to invest in France compared to permanent migrants. Below, we examine whether this difference in behavior between temporary and permanent migrants persists once we control for individual characteristics and the potential endogeneity between remigration plans and behavior.

\section{Methodology}

\subsection{Remigration Intentions and Home Outcomes}

Our first interest lies in determining how remigration intentions affect immigrants' investment behavior, both in France and in their country of origin. We first consider the following five binary investment outcomes related to the country of origin: Physical investment: (i) whether they remit money to the origin, (ii) whether they finance a project at origin, (iii) whether they own a house at origin; Non-monetary investment: (iv) whether they have an interest in the politics of their country of origin and (v) whether they participate in elections at origin.

The main challenge is that remigration intentions are potentially endoge- 
nous to our outcomes of interest (i.e. immigrants' behavior). An endogeneity issue may arise due to the existence of confounding factors. More specifically, intrinsic attachment to the country of origin is potentially positively correlated to both willingness to leave and outcomes such as remittances, investment in the country of origin, participation in elections at origin etc. This issue would bias our coefficient of interest upward. Furthermore, we could have a reverse causality problem if outcomes such as owning a house at origin or interest in the politics of the origin country were actually causing the intention to leave, rather than the other way around.

To circumvent this issue, we use a plausibly exogenous shifter for remigration intentions: opinion of the migrant about the level of discrimination in France. The idea is that if migrants think that discrimination in France is widespread, they are certainly more likely to be willing to leave or return to their home country. de Coulon et al. (2016) confirmed this in a recent quasi-experimental setting (i.e. the media coverage of a particularly tragic murder committed by a Romanian immigrant in Italy). They find that exposure to anti-immigrant attitudes impacts the intended duration of stay in the host country. In particular, immigrants who experience an increase in negative media feedback are those that predominantly increase their intention to leave. Moreover, the opinion about discrimination in France is not likely to influence the outcomes through a channel other than remigration intentions. This variable captures the perceived level of discrimination in France in general, not particular discriminatory acts against the individual, which could affect immigrant's behavior beyond remigration intentions. One might be concerned about the potential correlation between our instrument and wages. Indeed, it is plausible that migrants in low-pay jobs tend to think that discrimination is more widespread in France, by just generalizing their own case. We control for socio-professional categories, which proxy for income in the main model and check the robustness using income later. ${ }^{9}$

We estimate a recursive bivariate probit model where we estimate jointly (i) remigration intentions and (ii) immigrants' behaviour, but remigration intention also appears in the immigrant's outcome equation directly (i.e. we use a recursive simultaneous equation model where both dependent variables

\footnotetext{
${ }^{9}$ Income is not used as a control in our benchmark estimations due to concerns about self-selection of respondents to that question (see Section 5.3).
} 
are binary, and one of the dependent variables is endogenous), as follows:

$$
\begin{aligned}
R_{i} & =\alpha_{0}+\alpha_{1} X_{i}+\alpha_{2} Z_{i}+u_{i} \\
B O_{i} & =\beta_{0}+\beta_{1} R_{i}+\beta_{2} Z_{i}+v_{i}
\end{aligned}
$$

where $B O_{i}$ is a binary variable indicating migrant's behaviour relative to the origin country. Remigration intention is denoted by $R_{i}$ and $X_{i}$ is the exclusion restriction with $X_{i}=1$ if the migrant believes that France is a very discriminative country. $Z_{i}$ is a vector of individual characteristics (gender, marital status, age, age at arrival, education, region of residence, urban status, region of origin). Moreover, income could be correlated to both willingness to leave and outcomes such as remittances or owning a house at origin. This could in particular bias the coefficient of interest downwards if low income correlates to a high willingness to remigrate. In order to mitigate this problem we control for the employment status as well as socio-professional categories to proxy for income. $u_{i}$ and $v_{i}$ are error terms distributed as bivariate normal, each with a mean of zero, and variance-covariance matrix $V$, where $V$ has values of 1 on the leading diagonal. ${ }^{10}$

As argued by Wilde (2000) and similarly by Greene (2008), identification is achieved through functional form in recursive bivariate models. ${ }^{11}$ However, we still include exclusion restriction $X_{i}$ to provide plausibly exogenous variation in remigration intentions, $R_{i}$. Our coefficient of interest is $\beta_{1}$ capturing the impact of remigration intentions on the outcome.

Though the bivariate probit is arguably the most suitable estimation technique in our case, we also run 2-stage least square (2SLS) as a robustness check. The main disadvantage of that technique in our case is that it disregards the binary nature of our outcomes so that marginal effects predicted by the model might not lie between 0 and 1 . The advantage instead is that coefficients may be directly interpreted as marginal effects. It is also convenient to formally test the strength of our instruments. For completeness, we also run a simple probit and a linear probability model to compare the

\footnotetext{
${ }^{10}$ Setting the variance to 1 is a normalisation that just transforms the variance covariance matrix into a correlation matrix which is easier to interpret. This is a standard assumption in bivariate probit models. See Greene (2008) and Monfardini and Santos Silva (2008).

11 "In contrast to linear simultaneous equations with only continuous endogenous variables in recursive multiple equation probit models with endogenous dummy regressors no exclusion restrictions for the exogenous variables are needed if there is sufficient variation in the data. The last condition is ensured by the assumption that each equation contains at least one varying exogenous regressor" (Wilde, 2000).
} 
coefficients with and without instrumentation in order to infer the sign of the bias (see Tables 5 and A1).

\subsection{Remigration Intentions and Host Outcomes}

We use the same methodology to estimate the effect of remigration intentions on outcomes that concern the host country, mainland France.

$$
\begin{aligned}
R_{i} & =\alpha_{0}+\alpha_{1} Y_{i}+\alpha_{2} Z_{i}+u_{i} \\
B F_{i} & =\beta_{0}+\beta_{1} R_{i}+\beta_{2} Z_{i}+v_{i}
\end{aligned}
$$

where $B F_{i}$ is migrants' behavior in France and $R_{i}$ is an indicator for the remigration intention. As in equation $1.1, Z_{i}$ is a vector of individual characteristics and $Y_{i}$ is the exclusion restriction. The outcomes of interest here are the binary variables that indicate monetary investment: (i) owning a house in France; skill investment: (ii) improvement in French since arrival; and non-monetary investment : (iii) interest in French politics.

There is again a potential endogeneity problem and in particular a risk of reverse causality, in the sense that little investment in France may lead to poor economic outcomes and a higher willingness to remigrate. For example, an individual could want to leave because she has not managed to buy a house in France. Therefore, for identification and rather than relying solely on functional form, we use an instrument that captures the attachment to the home country but does not affect the investment decision in France through any additional channel. We use whether individuals want to be buried in France or abroad (i.e. $Y_{i}=1$ if individuals want to be buried outside France and 0 otherwise), as those who would like to be buried in France are less likely to intend to remigrate. Burial place should not be correlated with interest in French politics, French language improvement nor owning a house in France by any other channel than that of remigration intentions. We assume that burial intentions are less likely to be revised as a consequence of the more or less successful current migration experience, but still are an important driver of remigration intentions in the long-run.

As in the previous subsection, our baseline specification uses a recursive bivariate probit estimation procedure. However, we repeat the exercise using 2SLS and compare these results to their non-instrumented counterparts namely simple probit and linear probability model.

It is important to discuss here a limitation of our data, namely that we only observe individuals at one point in time. Therefore, we are not 
able to control for previous behavior that might be correlated with current decisions. In other words, it is possible that individuals do not invest at origin (i.e. remit) today because they have done so in the past or plan to do so in the future though they still plan to leave. Thus, our estimates could be downward biased for the outcomes (i.e. such as remittances). However, since we study an array of outcomes, it is unlikely that a bias is encountered across all outcomes. Moreover, our interest is in how current remigration intention affects current behavior.

\subsection{Trade-off between Outcomes}

Finally, we study the existence of a potential trade-off/complementarity between home and host outcomes caused by remigration intentions. More precisely, we want to uncover whether temporary migrants tend to substitute investment in the host country by investment in the origin country. We want to know how remigration intentions affect immigrants' behavior at home versus host countries e.g. are temporary migrants less likely to remit if they are investing in a house in France, or are temporary migrants less likely to invest in a house at origin if they are investing in a house in France? To this end, we estimate the following 3 -equation recursive multivariate probit model:

$$
\begin{aligned}
R_{i} & =\alpha_{0}+\alpha_{1} X_{i}+\alpha_{2} Z_{i}+u_{i} \\
B O_{i} & =\beta_{0}+\beta_{1} R_{i}+\beta_{2} P_{i}+\beta_{3} Z_{i}+v_{i} \\
B F_{i} & =\gamma_{0}+\gamma_{1} R_{i}+\gamma_{2} Z_{i}+w_{i}
\end{aligned}
$$

$R_{i}, B O_{i}$ and $B F_{i}$ are, as previously, remigration intention, investment in the country of origin and investment in France respectively. $Z_{i}$ is a vector of individual characteristics. $u_{i}, v_{i}$ and $w_{i}$ are error terms distributed as multivariate normal, each with a mean of zero, and variance-covariance matrix $V$, where $V$ has values of 1 on the leading diagonal and correlations $\rho_{j k}=\rho_{k j}$, with $(i, j, k) \in 1,2,3$, as off-diagonal elements. The model has a structure similar to that of a seemingly unrelated regression (SUR) model, except that the dependent variables are binary indicators. As for the SUR case, the equations need not include exactly the same set of explanatory variables.

We face the same endogeneity issues as previously but have one additional equation to estimate. Consequently, we need a second exclusion restriction 
in order to assess the potentially causal pathway between remigration intentions and the outcomes. To this end, we instrument remigration intention by $X_{i}$ opinion about discrimination in France as done previously. Additionally, we use $P_{i}$ presence of a parent (mother and/or father) abroad as an exclusion restriction for the country of origin outcome. The idea is that, controlling for observable characteristics, the presence of a parent abroad should induce individuals to increase their investment in the country of origin, be it either financially (remittances, project, ownership) or non financially (political interest and participation). Yet, it should not affect directly the intention to leave nor the host country outcome (such as own a house in France, interest in French politics or language improvement in French).

We focus on trade-offs between home and host-country outcomes since it is challenging to identify an instrument that would predict only one of two outcomes in the same country, without affecting the other one directly. Because it is not clear how financial and non financial outcomes are intertwined, we start by analyzing the purely monetary outcomes trade-offs followed by the non-monetary outcome trade-offs.

\section{Empirical Analysis}

\subsection{Remigration Intentions and Migrants' Investment Behavior}

Table 3 presents our main set of results using the recursive bivariate probit. Standard errors are clustered at the country of origin level. ${ }^{12}$ Remigration intentions increase the probability to invest in the origin country as shown by the positive, albeit not always significant, coefficients in the first five columns. On the other hand, intention to remigrate tends to decrease the probability to invest in the host country, as shown by the negative coefficients in columns (6) to (8). For host country outcomes, the negative effect of remigration intention is very significant for improvement in French and house ownership in France, but not significant (although signed consistently) for interest in politics in France.

INSERT Table 3: Bi-probit: Full sample and Africans only

INSERT Table 4: Bi-probit: Predicted probabilities

\footnotetext{
${ }^{12}$ Results are highly robust to clustering at the region of residence level. Tables are available upon request.
} 
The pattern described earlier seems to be heavily driven by migrants from Africa, the most important immigrant group in France. Indeed, those who desire to leave increase significantly their investment towards their origin country and decrease that in France. Only interest in politics in France is not significantly affected by remigration intention for this subsample.

Interestingly, in terms of language skills, we find that those who plan to remigrate are less likely to have experienced improvements compared to those who intend to stay. We control for the level of French upon arrival and whether the country of origin and France share French as an official language or if French is spoken by at least $9 \%$ of the population (as in Mayer and Zingano, 2011). Furthermore, improvement in French between time of arrival and the time of survey is not only based on self-reporting but also on a French test that was administrated as part of the survey. ${ }^{13}$ Another interesting finding is that remigration intentions increase interest in politics and participation in elections at origin, particularly for Africans, suggesting another channel through which temporary migration impacts economic development and political institutions at home.

Table 4 shows by how much intention to leave affects outcomes. In order to get the magnitude of the effect, we predict the following probabilities: $P\left[B O_{i}=1 \mid R_{i}=1\right]$ and $P\left[B O_{i}=1 \mid R_{i}=0\right]$, where $B O_{i}$ is the outcome at origin and $R_{i}$ is the intention to remigrate. Thus, we can observe how the probability of each of the outcomes (e.g. to remit) is affected by the intention to leave. In the full sample, remigration intention does not significantly impact the likelihood of monetary investment at origin (except increasing the probability of investing in a project at origin) but does increase political interest and political participation at origin. At the same time, intention to leave decreases the probability to own a house in France by about 22 percentage points (p.p.) and that to improve in French by 12 p.p.. For African immigrants, remigration intentions have a substantial impact on the probability of remitting and investing at home, whilst also reducing the incentives to invest in France. Conditional on intention to remigrate, 54\% of African immigrants are likely to remit compared to $20 \%$ if they are not planning to leave. The probability of non-monetary outcomes also increases by a large amount with (59 and 48 percentage points respectively for the probability to participate in elections and to be interested in politics at origin).

\footnotetext{
${ }^{13}$ As a robustness, we checked whether immigrants enrolled in French classes since arrival, but the sample is too small for any robust analysis.
} 
Now, we run a naive probit model, as if remigration intentions were exogenous, in order to check whether instrumenting makes a big difference. The general pattern remains similar: positive coefficient on remigration intention for outcomes related to the origin country and negative for outcomes in France. However, some differences arise. In the full sample probit, remigration intentions appear to matter significantly for all outcomes except for owning a house in France, while they do not for remitting and owning a house at origin in the bi-probit. In all cases when remigration intentions turn out significant, the coefficient is bigger in the bi-probit than in the probit, pleading for the presence of an attenuation bias when we do not instrument.

INSERT Table 5: Probit: Full sample and Africans only

For comparison purposes, we repeat the exercise using a 2SLS procedure instead of the bivariate probit and a linear probability model (LPM) instead of the probit. Results are presented in Tables A1 and A2. The picture remains overall similar. Indeed, the coefficient on remigration intentions is generally positive for outcomes related to the origin country and negative for outcomes in France. In the full sample 2SLS, significance is not achieved only for owning a house and participation in elections at origin, as well as interest in politics in France. The effect of remigration intentions is stronger in the subsample of Africans. Looking at F-statistics of the first stage, we find that our instruments are not weak as the value is above 10 . Using the comparison with the LPM, we confirm that coefficients are larger in absolute value in the 2SLS, reinforcing the idea that the instrumentation is useful to correct an attenuation bias.

\subsection{Remigration Intentions and Joint Home-Host Investment Decisions}

One interesting question we tackle is whether remigration intentions still impact investment decisions when we consider them jointly. In particular, we examine the possible trade-off between behavior at origin $\left(\mathrm{BO}_{i}\right)$ and behavior at host $\left(B F_{i}\right)$. To this end, we first run a linear specification (3SLS) to check the significance of our instruments. We find that our two instrumental variables (opinion about discrimination and parent abroad) are overall significant in the full sample (see Table A3).

We then run our multiple equation probit estimations as described in Section 4.2. Table A4 shows the full results. We focus on marginal probabilities 
shown in Table 6 and 7 for simplicity. We calculate the probabilities of $B O_{i}$ and $B F_{i}$ conditional on desiring to remigrate. We compute the probability of $B O_{i}=1$ and of $B F_{i}=1$ fixing $R_{i}$ to 0 and 1 successively.

INSERT Table 6: Tri-probit: Predicted probabilities - Full sample INSERT Table 7: Tri-probit: Predicted probabilities - Africans only

Results for the full sample show the existence of a substantial substitution effect between investment in the origin country and in France, in particular for monetary outcomes. Temporary migrants are at the same time more likely to remit, have a project or own a house at origin and less likely to own a house in France or improve in French. On the other hand, non-monetary outcomes at origin and in France seem to be complementary. Indeed, temporary migrants are both more likely to be interested in politics at origin and in France. The same complementarity holds for participation in elections at origin.

When we focus on migrants from Africa only, the picture is qualitatively similar but the effect of remigration intentions on outcomes in France decreases in size and loses significance. We interpret these results as suggestive evidence of the existence of a trade-off between investing at origin and at destination for temporary migrants. However, we should also take these results with caution as they become less significant when we focus on the subsample of Africans only. This could be due to the reduction in the sample size, but also to the fact that we look only at extensive and not intensive margins. Migrants may find it optimal to keep a diverse portfolio even if they decide to remigrate. Nevertheless, some substitution on the intensive margin between investment at home and at host could be occurring, but we do not observe it in this data.

Finally, we examine the possibility of trade-offs between two home monetary outcomes, namely: remitting and owning a house at origin; remitting and investing in a project at origin and finally owning a house at origin and investing in a project at origin. Finding a valid exclusion restriction in this case is problematic since we are dealing with two home outcomes simultaneously. We therefore rely on the functional form for identification. Table A5 provides results for the three possible pairwise combinations of monetary home outcomes, using a trivariate probit model with a remigration intention equation (and remigration intention as a control in the two equations of the 
home variables). We find that the correlations between the two home outcomes are always positive and significant. Thus, overall this suggests that there is a complementarity between the home outcomes we are examining.

Overall our results using the trivariate probit reinforce those from the bi-probit analysis. Indeed, we can confirm that not only does intention to remigrate affect both investment at host and at home in opposite directions, but as well that it is very likely that temporary migrants do substitute the former for the latter. Of course more research is required on the topic, in particular using panel data and intensive margin decisions.

\subsection{Robustness checks}

(a) Definition of Temporary: In order to test the robustness of our results, we first change the way we define the intention to leave France by including respondents who answered the question on the intention to leave France with "Maybe" among temporary migrants. Table A6 shows that results are globally consistent. The only notable difference is that a larger definition of intention to leave France significantly increases the effect we find on remittances. This is indicative that our results mainly dwell upon the comparison between migrants who are certain either to leave France or to remain, rather than upon a possible misclassification of migrants with uncertain plans.

Secondly, we focus on temporary migrants only and compare the behavior of those who have taken steps towards leaving from those who have not in Table A7. Individuals who have started to plan their departure from France are more likely to have invested at origin, to be interested in politics in France while being significantly less likely to own in France. These somewhat weaker results could be due to the large drop in sample size when we focus on temporary migrants only. They could also be due to the fact that we look at a subsample that is overall more homogenous as they all stated some desire to leave. It may explain in particular the lack of effect we observe on political interest and participation in elections at origin. Combined with the drop in sample size and increased homogeneity, both the fact that we look only at extensive margin decisions and the cross-sectional nature of the data may also help to explain the differences in results.

(b) Leave and Return: We investigate whether our results are driven primarily by migrants wishing to return to their origin country or by those wishing to migrate in a third country. In Table A8, we first define temporary migrants as those who wish to return to their country of origin and compare 
them to all other observations (except those who express a desire to leave France for a third country). The only difference with the baseline estimation is that project of origin is no longer significantly impacted by a return decision. Then, we compare return migrants to stayers only (i.e. those who state a clear desire to remain in France, removing those who answer "I don't know" or "maybe") and find that improvement in French is no longer significant, although keeping the negative sign. Finally, we compare those who wish to leave (i.e. return to origin or leave to a third country) to stayers. Results are consistent with the benchmark specification. The pattern of a positive effect of remigration intention on outcomes related to the origin country and negative effect for outcomes in France holds qualitatively in all instances, whereas only marginal changes in the magnitude of the coefficients are observed in most cases.

(c) Sample Selections: We additionally run several checks trimming the sample in different directions. In Table A9, we restrict the sample to individuals who accepted to declare their income in order to see whether controlling for income would change our results. Although this procedure biases the sample, as a large proportion of the self-employed respondents is dropped, our previous results still hold. We also run our estimations excluding individuals aged 16 or less at the moment of arrival (often referred to as generation 1.5, as they lie between the first and the second generation of immigrants). It can be argued that these immigrants did not take the decision to migrate themselves but were rather following their family. Given that they have spent part of their youth and a substantial part of their life in France, their attachment and behavior towards their country of origin might differ from migrants who moved to France in order to work there (i.e. first generation migrants). These individuals constitute roughly one third of our sample. Table A10 shows that results remain largely consistent when we exclude them from our sample, with the sole exception that remigration intention significantly decreases interest in French politics among immigrants who were older than 16 when they arrived in France. For similar concerns, we also repeat the exercise excluding students from the sample, as they may be motivated by very different reasons than other migrants. Results in Table A11 are very similar to the baseline estimations.

In the same spirit, in Table A12, we run our estimations on a sub-sample excluding individuals born in DOM, i.e. French Oversea Territories. Given that these 712 individuals generally have the French nationality and free mobility between their territory of origin and mainland France, they could 
be expected to behave differently from other immigrants. Investing in a project at origin is no longer significantly affected by intention to leave. The rest of our baseline results remain however broadly consistent in terms of sign and size of the coefficient of interest.

(d) Alternative Instrumentation: We also explore alternative ways of instrumenting in Table A13. In particular, we use an additional instrument on top of those already described. Namely, we construct the share of migrants who declare they wish to leave France by country of origin and assign this share to each individual in the sample. The idea is that migrants belonging to communities who are on average more likely to desire to leave France should tend to be influenced in that direction. We keep the first instrument as well in order not to rely uniquely on cross-origin country variation in the instrument. Results remain very similar to those with only one instrument. The only notable difference is that intention to leave significantly increases home ownership at origin in this specification.

\section{Conclusion}

This paper studies how remigration intentions affect immigrants' behavior. Using a unique French data set, we analyze the relationship between remigration intentions and several immigrants' outcomes in the host and origin country. The findings show that temporary migrants behave differently from permanent ones. Temporary migrants are more likely to display higher attachment to the home country, in particular in the form of non-monetary outcomes such as political interest. Also, remigration intentions are associated with lower monetary and non-monetary (human capital and political) investment in the host country. Examining the potential trade-off between home and host countries' outcomes, we find a negative correlation (i.e. a tradeoff) between immigrants' investments at the home and at the host country: immigrants who intend to remigrate significantly decrease their investment in France while simultaneously increasing their investment at origin. However, interestingly, we do find complementarity between interest in politics at home and host countries. Furthermore, home outcomes seem to exhibit some complementarity: an immigrant who uses one investment channel towards her origin country (i.e. remit) is also more likely to use a second one (i.e. invest in a project).

Immigrants from Africa, the main region of origin, significantly increase their monetary (and non-monetary) investment at origin and decrease their 
investment in France when they intend to leave France. The observed tradeoff between home and host outcomes for African immigrants is however not as strong and significant as for the full sample.

Overall, our results suggest that temporary migrants behave differently from permanent ones in the host country and particularly tend to limit their non-monetary investment such as the host country's language. Moreover, our findings suggest that there might potentially be a trade-off between home and host investments for temporary migrants. This might limit their assimilation in the host country, which can be particularly problematic if remigration intentions do not materialize. Hence, those behavioral differences should be taken into account in the migration policy debate, in particular at times were temporary migration policies are increasingly preferred over other migration schemes by many governments.

\section{References}

[1] Amuedo-Dorantes, Catalina and Susan Pozo (2006), Remittances as insurance: evidence from Mexican immigrants, Journal of Population Economics vol.19(2), pages 227-254.

[2] Batista, Catia and Janis Umblijs (2016), Do migrants send remittances as a way of self-insurance?, Oxford Economic Papers, vol. 68(1), pages 108-130.

[3] Batista, Catia, Dan Silverman and Dean Yang (2015), Directed giving: Evidence from an inter-household transfer experiment, Journal of Economic Behavior and Organization, vol. 118(C), pages 2-21.

[4] Bauer, Thomas and Mathias Sinning (2011), The savings behavior of temporary and permanent migrants in Germany, Journal of Population Economics, vol. 24(2), pages 421-449.

[5] Bijwaard, Govert (2010), Immigrant migration dynamics model for The Netherlands, Journal of Population Economics, vol. 23 (4), pages 12131247.

[6] Borjas, George J. and Bernt Bratsberg (1996), Who Leaves? The Outmigration of the Foreign-Born, The Review of Economics and Statistics, vol. 78(1), pages 165-176. 
[7] Coniglio, Nicolas, De Arcangelis, Giuseppe and Laura Serlenga (2009), Intentions to leave of Undocumented Migrants: Illegality as a Cause of Skill Waste, Review of Development Economics, vol. 13, issue 4, pages 641-657.

[8] Coniglio, Nicolas, De Arcangelis, Giuseppe and Laura Serlenga (2010), leave Decisions of Undocumented Migrants: Do Network Effects Help the High-Skilled Overstay? Labour, vol. 24, pages 93-113.

[9] De Arcangelis, Giuseppe and Majlinda Joxhe (2015), How do migrants save? Evidence from the British Household Panel Survey on temporary and permanent migrants versus natives, IZA Journal of Migration, vol. 4(1), pages 1-23, December.

[10] De Arcangelis, Giuseppe, Majlinda Joxhe, David McKenzie, Erwin Tiongson and Dean Yang (2015), Directing remittances to education with soft and hard commitments: Evidence from a lab-in-the-field experiment and new product take-up among Filipino migrants in Rome, Journal of Economic Behavior and Organization, vol. 111(C), pages 197208.

[11] de Coulon, Augustin, Dragos Radu and Max Friedrich Steinhardt (2016), Pane e Cioccolata: The impact of native attitudes on return migration, Review of International Economics, vol. 24(2), pages 253281, 05 .

[12] Delpierre, Matthieu and Bertrand Verheyden (2014), Remittances, savings and leave migration under uncertainty, IZA Journal of Migration, vol. 3(1), pages 1-43, December.

[13] Djajic, Slobdan (1989), Migrants in a guest-worker system: a utility maximizing approach, Journal of Development Economics, vol. 31(2), pages 327-339.

[14] Djajic, Slobodan and Ross Milbourne (1988), A general equilibrium model of guest-worker migration: a source-country perspective. Journal of International Economics, vol. 25(3-4), pages 335-351.

[15] Dustmann, Christian (1997), Return migration, uncertainty and precautionary savings, Journal of Development Economics, vol. 52(2), pages 295-316. 
[16] Dustmann, Christian (1999), Temporary Migration, Human Capital, and Language Fluency of Migrants, Scandinavian Journal of Economics, vol. 101(2), pages 297-314.

[17] Dustmann, Christian and Joseph-Simon Görlach (2016), The Economics of Temporary Migrations, Journal of Economic Literature, vol. 54(1), pages 98-136.

[18] Dustmann, Christian and Josep Mestres (2010), Remittances and temporary migration, Journal of Development Economics, vol. 92(1), pages $62-70$.

[19] Galor, Oded and Oded Stark (1991), The probability of leave migration, migrants' work effort, and migrants' performance, Journal of Development Economics, vol. 35(2), pages 399-405.

[20] Greene, William H. (2008), Econometric Analysis, Prentice Hall.

[21] Kirdar, Murat (2009), Labor market outcomes, savings accumulation, and leave migration, Labour Economics, vol. 16(4), pages 418-428.

[22] Merkle, Lucie and Klaus Zimmermann (1992), Savings, remittances, and leave migration, Economic Letters vol. 38(1), pages 77-81.

[23] Mayer, Thierry and Soledad Zignago (2011), Notes on CEPII's distance measures (GeoDist). CEPII Working Paper 2011-25.

[24] Monfardini, Chiara and Joao Santos Silva (2008), What can we learn about correlations from multinomial probit estimates?, Economics Bulletin, vol. 3(28), pages 1-9.

[25] Ruyssen, Ilse, and Sara Salomone (2015), Female migration: a way out of discrimination. CESifo working paper No. 5572.

[26] Torero, Máximo and Angelino Viceisza (2015), To remit, or not to remit: that is the question. A remittance field experiment, Journal of Economic Behavior and Organization, vol. 112(C), pages 221-236.

[27] Wilde J. (2000), Identification of Multiple Equation Probit Models with Endogenous Dummy Regressors, Economics Letters, vol. 69(3), pages 309-312. 
[28] Wolff, François-Charles (2015), Do the Return Intentions of French Migrants Affect Their Transfer Behaviour?, The Journal of Development Studies, vol. 51(10), pages 1358-1373.

[29] Wooldridge, J. M. (2010), Econometric analysis of cross section and panel data. MIT press. 


\section{Appendices}

\section{A Descriptive statistics of the sample used}

The survey we use is representative of the total French population. The sample of immigrants is drawn from the 2007 French Census. It is stratified in order to be representative of the full immigrant population aged 18-59 living in France, but making sure at the same time that origins that are too scarce to be surveyed in sufficient numbers using a random sampling methodology reach reasonable sizes. These scarce origins have been chosen to allow the comparison with a previous survey called MGIS, "Mobilité Géographique et Insertion Sociale" (geographic mobility and social inclusion) and include immigrants from Vietnam, Laos and Cambodia, Turkey, Central Africa, the Gulf of Guinea and Western Sahel. A considerable effort has been put by the designers of the survey to ensure representativeness of the data.

The sample that we use is restricted to the first generation immigrants (i.e. individuals born outside mainland France). The mean age in the sample is 41.5 years and mean age at arrival is 19.9 years. $53.1 \%$ of the sample is female. $73.4 \%$ of respondents share the household with a partner, $24.9 \%$ are single while the remaining $1.7 \%$ have a partner living outside the household. $22.3 \%$ live in agglomerations with less than 50,000 inhabitants and $64.8 \%$ in agglomerations with more than 200,000 inhabitants. $16.6 \%$ completed primary, $27.4 \%$ secondary school and $14.9 \%$ a vocational training. $22.6 \%$ finished up to 2 years of college and $18.6 \%$ have a master degree.

$68 \%$ of respondents are active and employed $(60.7 \%$ of respondents are waged and $7.3 \%$ self-employed) while $9.3 \%$ are unemployed. $3.5 \%$ of respondents are students and $19.2 \%$ are inactive (including the retired). Almost one third $(30.2 \%)$ of the respondents benefited from a family reunion program or married a French citizen. $15.4 \%$ own a worker visa and $11.1 \%$ a student visa. Asylum seekers make up $10.6 \%$ of the sample while $15 \%$ of respondents benefited from a legal visa waiver. $54.6 \%$ of respondents have a parent at origin country and $7.5 \%$ a child. $39.7 \%$ own a house in France.

The survey allows to proxy the links kept with origin country. $21.8 \%$ of respondents state that they send remittances to people outside their household and $12.1 \%$ finance a project at origin. $16.3 \%$ participate in political elections at origin.

The language skills that migrants had upon arrival are variable. $40 \%$ state 
Table 1: Characteristics of immigrants by remigration intention

\begin{tabular}{|c|c|c|c|c|}
\hline & Full sample & Intention to leave & Intention to stay & Difference \\
\hline Age in 2008 (average) & 41.5 & 39.4 & 41.9 & $2.556^{* * *}$ \\
\hline Female (\% of the sample) & $53.1 \%$ & $51.3 \%$ & $53.5 \%$ & 0.022 \\
\hline Parent at origin (\% Yes) & $54.5 \%$ & $65.1 \%$ & $52.6 \%$ & $-0.125^{* * *}$ \\
\hline Child at origin (\% Yes) & $7.5 \%$ & $8.8 \%$ & $7.2 \%$ & $-0.015^{* *}$ \\
\hline \multicolumn{5}{|l|}{ Investment Behaviour } \\
\hline Remit & $15.0 \%$ & $19.9 \%$ & $14.1 \%$ & $-0.058^{* * *}$ \\
\hline Own house outside France & $19.3 \%$ & $30.3 \%$ & $17.2 \%$ & $-0.130^{* * *}$ \\
\hline Project at origin & $1.3 \%$ & $2.6 \%$ & $1.0 \%$ & $-0.070^{* * *}$ \\
\hline Own house in France & $39.7 \%$ & $28.4 \%$ & $41.7 \%$ & $0.133^{* * *}$ \\
\hline Participation in elections outside France & $15.9 \%$ & $19.1 \%$ & $15.3 \%$ & $-0.038^{* * *}$ \\
\hline
\end{tabular}

that they did not speak French at all while $1.3 \%$ stated a very good level at speaking and understanding and $26.9 \%$ a proficient level in everything. $58.4 \%$ however declare that language skills improved since arrival and $52.1 \%$ declare to be proficient in all the aspects of French language at the time of survey. 
Table 2: Characteristics of immigrants by remigration intention, continued

\begin{tabular}{|c|c|c|c|c|}
\hline & Full sample & Intention to leave & Intention to stay & Pearson's $\chi^{2}$ (p-value) \\
\hline Origin & & & & $477.905(0.000)$ \\
\hline DOM & $7.8 \%$ & $19.7 \%$ & $5.5 \%$ & \\
\hline Europe & $25.7 \%$ & $22.2 \%$ & $26.4 \%$ & \\
\hline North Africa & $24.3 \%$ & $14.3 \%$ & $26.1 \%$ & \\
\hline Subsaharan Africa & $15.3 \%$ & $22.7 \%$ & $13.9 \%$ & \\
\hline Asia & $21.3 \%$ & $15.6 \%$ & $22.3 \%$ & \\
\hline Other & $5.7 \%$ & $5.5 \%$ & $5.7 \%$ & \\
\hline Completed education & & & & $24.698(0.000)$ \\
\hline Up to primary & $16.6 \%$ & $15.6 \%$ & $16.8 \%$ & \\
\hline Secondary schooling & $27.4 \%$ & $25.0 \%$ & $27.8 \%$ & \\
\hline Vocational training & $14.9 \%$ & $13.4 \%$ & $15.2 \%$ & \\
\hline Up to bachelor degree & $22.6 \%$ & $23.2 \%$ & $22.5 \%$ & \\
\hline Master degree & $18.6 \%$ & $22.9 \%$ & $17.8 \%$ & \\
\hline Marital Status & & & & $52.375(0.000)$ \\
\hline Single & $24.9 \%$ & $30.1 \%$ & $23.9 \%$ & \\
\hline Cohabiting partner & $73.4 \%$ & $66.7 \%$ & $74.7 \%$ & \\
\hline Non-Cohabiting partner & $1.7 \%$ & $3.2 \%$ & $1.4 \%$ & \\
\hline Size of residence place & & & & $70.753(0.000)$ \\
\hline$<50.000$ inhab. & $22.3 \%$ & $16.7 \%$ & $23.4 \%$ & \\
\hline$<200.000$ inhab. & $12.9 \%$ & $10.7 \%$ & $13.3 \%$ & \\
\hline$<1.000 .000$ inhab. & $26.2 \%$ & $24.6 \%$ & $26.5 \%$ & \\
\hline$>1.000 .000$ inhab. & $38.6 \%$ & $48.0 \%$ & $36.9 \%$ & \\
\hline Employment status & & & & $83.028(0.000)$ \\
\hline \multicolumn{5}{|l|}{ Active } \\
\hline Waged & $60.7 \%$ & $62.3 \%$ & $60.4 \%$ & \\
\hline Self-Employed & $7.3 \%$ & $6.4 \%$ & $7.5 \%$ & \\
\hline Unemployed & $9.3 \%$ & $8.4 \%$ & $9.5 \%$ & \\
\hline Inactive (including retired) & $19.2 \%$ & $15.6 \%$ & $19.8 \%$ & \\
\hline Students & $3.5 \%$ & $7.2 \%$ & $2.8 \%$ & \\
\hline Employment category & & & & $24.426(0.000)$ \\
\hline Business owners and managing positions & $16.4 \%$ & $15.8 \%$ & $16.6 \%$ & \\
\hline Intermediate positions & $12.7 \%$ & $14.3 \%$ & $12.4 \%$ & \\
\hline Clerks and employes & $24.9 \%$ & $26.2 \%$ & $24.7 \%$ & \\
\hline Workers & $28.5 \%$ & $23.8 \%$ & $29.4 \%$ & \\
\hline Never worked and other inactive & $17.4 \%$ & $20.0 \%$ & $16.9 \%$ & \\
\hline Visa type at arrival & & & & $255.743(0.000)$ \\
\hline \multicolumn{5}{|l|}{ Family Reunion or } \\
\hline Married French citizen & $30.2 \%$ & $24.0 \%$ & $31.3 \%$ & \\
\hline Worker visa & $15.4 \%$ & $16.1 \%$ & $15.3 \%$ & \\
\hline Student visa & $11.1 \%$ & $14.5 \%$ & $10.4 \%$ & \\
\hline Asylum & $10.6 \%$ & $5.5 \%$ & $11.5 \%$ & \\
\hline Visa waiver & $15.0 \%$ & $26.7 \%$ & $12.8 \%$ & \\
\hline Other visa & $17.8 \%$ & $13.3 \%$ & $18.6 \%$ & \\
\hline French skills at arrival & & & & $156.206(0.000)$ \\
\hline Not at all & $40.0 \%$ & $31.7 \%$ & $41.6 \%$ & \\
\hline Knows some French & $31.7 \%$ & $26.5 \%$ & $32.7 \%$ & \\
\hline Understands and speaks & $1.3 \%$ & $1.4 \%$ & $1.3 \%$ & \\
\hline Proficient & $26.9 \%$ & $40.3 \%$ & $24.4 \%$ & \\
\hline
\end{tabular}

Note: Pearson's $\chi^{2}$ gives the p-value associated to the hypothesis that the rows and columns in a two-way table are independent. 
Table 3: Recursive Bi-probit: Full sample and Africans only

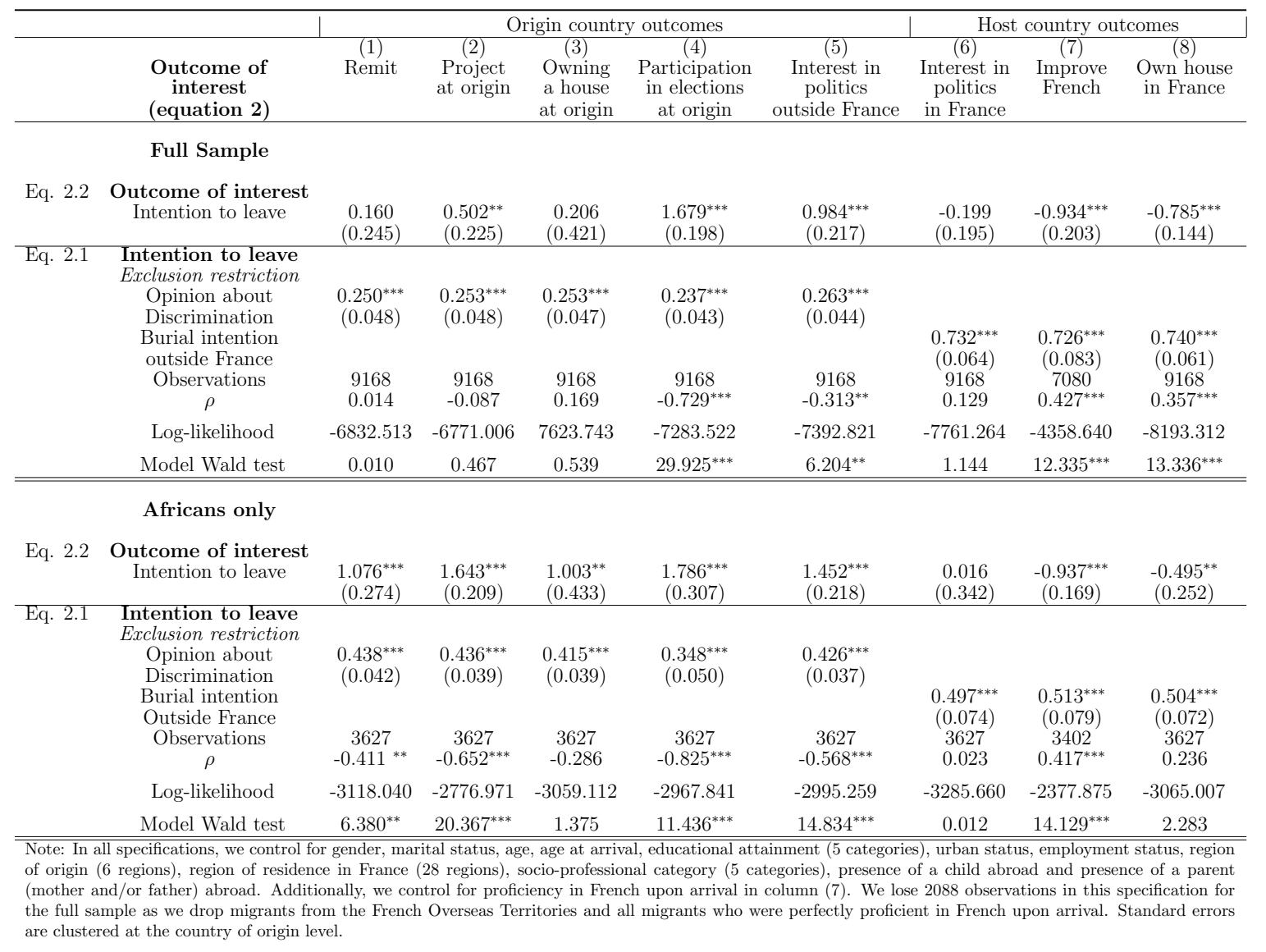

Table 4: Recursive Bi-probit: Predicted probabilities

\begin{tabular}{llcccccc}
\hline & & \multicolumn{3}{c}{ Full Sample } & \multicolumn{3}{c}{ African migrants } \\
\hline & & \multicolumn{3}{c}{ Conditional on } & Diff. & \multicolumn{3}{c}{ Conditional on } & Diff. \\
\hline & & Int. leave & Not & & Int. leave & Not & \\
\hline (1) & Remit & 17.7 & 14.4 & 3.3 & 53.6 & 19.8 & $33.8^{* * *}$ \\
$(2)$ & Project at origin & 21.9 & 10.6 & $11.3^{* *}$ & 62.4 & 10.7 & $51.7^{* * *}$ \\
$(3)$ & House at origin & 23.7 & 18.4 & 5.3 & 48.3 & 17.3 & $31.0^{* *}$ \\
$(4)$ & Election at origin & 65.0 & 13.0 & $52.0^{* * *}$ & 73.0 & 13.6 & $59.4^{* * *}$ \\
$(5)$ & Int. politics at origin & 42.2 & 12.9 & $29.3^{* * *}$ & 61.6 & 13.5 & $48.1^{* * *}$ \\
$(6)$ & Int. politics in France & 17.1 & 22.1 & -5.0 & 26.5 & 26.0 & 0.5 \\
$(7)$ & Improved French & 46.8 & 58.5 & $-11.7^{* * *}$ & 32.6 & 47.4 & $-14.8^{* * *}$ \\
$(8)$ & House in France & 21.7 & 43.4 & $-21.7^{* * *}$ & 15.4 & 26.9 & $-11.5^{* *}$ \\
\hline
\end{tabular}


Table 5: Probit: Full sample and Africans only

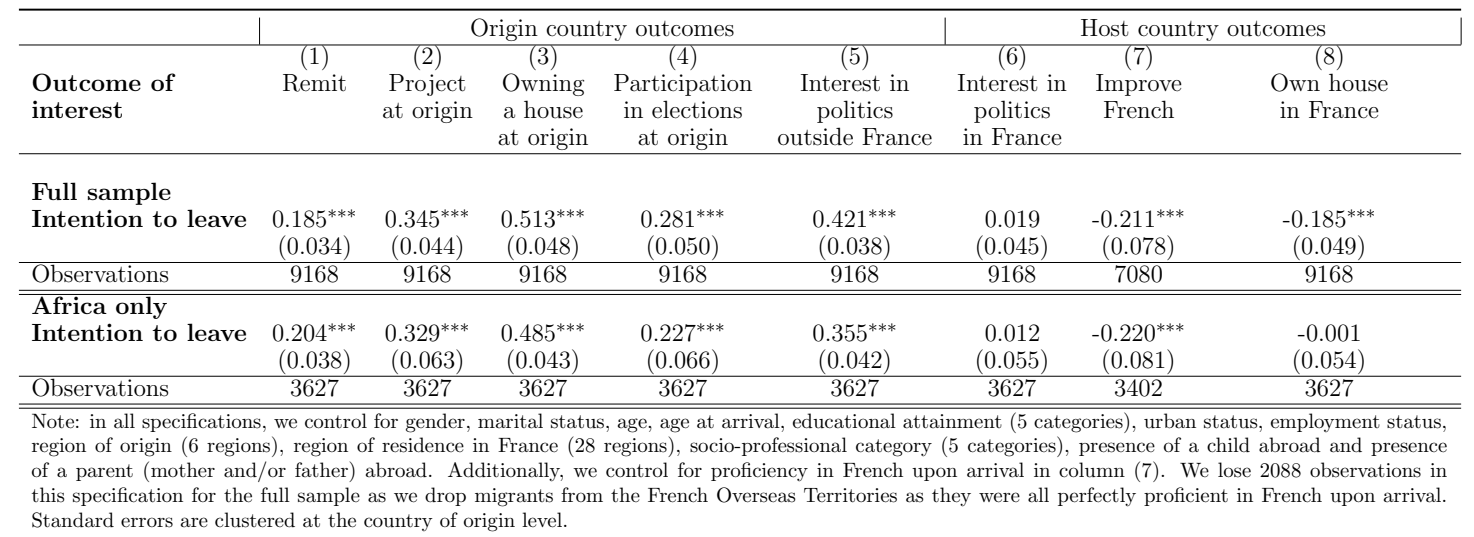

Table 6: Tri-probit: Full sample - Predicted probabilities

\begin{tabular}{clccc}
\hline & & \multicolumn{3}{c}{ Full Sample } \\
\hline & & Conditional on & Diff. \\
\hline & & Intention to leave & Not \\
\hline (1) & Remit & 18.1 & 14.4 & $3.7^{*}$ \\
& House in France & 33.7 & 40.8 & $-7.1^{* *}$ \\
$(2)$ & Project at origin & 20.3 & 10.8 & $9.5^{* * *}$ \\
& House in France & 33.7 & 40.8 & $-7.1^{* *}$ \\
$(3)$ & 31.2 & 17.2 & $14^{* * *}$ \\
& House at origin & 33.6 & 40.8 & $-7.2^{* *}$ \\
\hline House in France & Remit & 19.7 & 14.7 & $5^{* *}$ \\
& French language improvement & 58.7 & 62.9 & $-4.2^{* * *}$ \\
(5) & Project at origin & 20.5 & 11.3 & $9.2^{* * *}$ \\
& French language improvement & 58.7 & 62.9 & $-4.2^{* * *}$ \\
(6) & House at origin & 34.9 & 16.8 & $18.1^{* * *}$ \\
& French language improvement & 58.6 & 62.9 & $-4.3^{* * *}$ \\
(7) & Interest in politics at origin & 27.1 & 13.0 & $14.1^{* * *}$ \\
& French language improvement & 58.6 & 62.9 & $-4.3^{* * *}$ \\
$(8)$ & Election at origin & 31.3 & 15.8 & $15.5^{* * *}$ \\
& French language improvement & 58.6 & 63.0 & $-4.4^{* * *}$ \\
\hline (9) & Election at origin & 27.7 & 14.4 & $13.3^{* * *}$ \\
& Interest in politics in France & 26.8 & 20.2 & $6.6^{* *}$ \\
$(10)$ & Interest in politics at origin & 27.2 & 14.4 & $12.8^{* * *}$ \\
& Interest in politics in France & 25.5 & 20.4 & $5.1^{* *}$ \\
\hline
\end{tabular}


Table 7: Tri-probit: Predicted probabilities - African migrants

\begin{tabular}{|c|c|c|c|c|}
\hline & & \multicolumn{3}{|c|}{ African migrants } \\
\hline & & \multirow{2}{*}{\multicolumn{2}{|c|}{$\begin{array}{l}\text { Conditional on } \\
\text { Intention to leave Not }\end{array}$}} & Diff. \\
\hline & & & Not & \\
\hline (1) & Remit & 34.7 & 21.6 & $13.1^{*}$ \\
\hline & House in France & 23.7 & & -1.5 \\
\hline (2) & Project at origin & 28.5 & 12.0 & $16.5^{* * * *}$ \\
\hline & House in France & & 25.1 & -1.1 \\
\hline (3) & $\begin{array}{l}\text { House at origin } \\
\text { House in France }\end{array}$ & $\begin{array}{l}36.0 \\
23.7\end{array}$ & $\begin{array}{l}18.4 \\
25.2\end{array}$ & $\begin{array}{l}17.6^{* * * *} \\
-1.5\end{array}$ \\
\hline (4) & Remit & 37.0 & 21.4 & $15.6^{* * *}$ \\
\hline & French language imp. & 42.7 & 45.2 & -2.5 \\
\hline (5) & $\begin{array}{l}\text { Project at origin } \\
\text { French language imp }\end{array}$ & $\begin{array}{l}32.6 \\
42.5\end{array}$ & 12.0 & $20.6^{* * *}$ \\
\hline (6) & $\begin{array}{l}\text { French anguage } 1 \mathrm{mp} \text {. } \\
\text { House at origin }\end{array}$ & $\begin{array}{l}42.5 \\
34.1\end{array}$ & $\begin{array}{l}45.2 \\
18.3\end{array}$ & $15.8^{-2.7}$ \\
\hline & French language imp. & 42.6 & 45.2 & -2.6 \\
\hline (7) & Int. politics origin & 37.5 & 13.9 & $23.6^{* * *}$ \\
\hline & French language imp. & 42.8 & 45.1 & -2.3 \\
\hline (8) & Election at origin & 23.4 & 15.4 & $8.0^{* * *}$ \\
\hline & French language imp. & 42.4 & 45.2 & -2.8 \\
\hline (9) & Election at origin & 20.5 & 15.7 & 4.8 \\
\hline & Int. politics France & 31.1 & 25.3 & 5.8 \\
\hline (10) & Int. politics origin & 26.9 & 15.9 & $11.0^{* * *}$ \\
\hline & Int. politics France & 31.3 & 25.2 & 6.1 \\
\hline
\end{tabular}

Table A1: LPM: Full sample and Africans only

\begin{tabular}{|c|c|c|c|c|c|c|c|c|}
\hline \multirow[b]{2}{*}{$\begin{array}{l}\text { Outcome of } \\
\text { interest }\end{array}$} & \multicolumn{5}{|c|}{ Origin country outcomes } & \multicolumn{3}{|c|}{ Host country outcomes } \\
\hline & $\begin{array}{c}(1) \\
\text { Remit }\end{array}$ & $\begin{array}{l}(2) \\
\text { Project } \\
\text { at origin }\end{array}$ & $\begin{array}{c}(3) \\
\text { Owning } \\
\text { a house } \\
\text { at origin }\end{array}$ & $\begin{array}{c}(4) \\
\text { Participation } \\
\text { in elections } \\
\text { at origin }\end{array}$ & $\begin{array}{c}\text { (5) } \\
\text { Interest in } \\
\text { politics } \\
\text { outside France }\end{array}$ & $\begin{array}{c}\text { (6) } \\
\text { Interest in } \\
\text { politics } \\
\text { in France } \\
\end{array}$ & $\begin{array}{c}(7) \\
\text { Improve } \\
\text { French }\end{array}$ & $\begin{array}{l}\text { (8) } \\
\text { Own house } \\
\text { in France }\end{array}$ \\
\hline \multicolumn{9}{|l|}{ Full Sample } \\
\hline $\begin{array}{l}\text { Outcome of interest } \\
\text { Intention to leave }\end{array}$ & $\begin{array}{c}0.033^{\text {**** }} \\
(0.009) \\
9168 \\
0.145 \\
\end{array}$ & $\begin{array}{c}0.073^{* * *} \\
(0.011) \\
9168 \\
0.050 \\
\end{array}$ & $\begin{array}{c}0.143^{* * *} \\
(0.016) \\
9168 \\
0.103 \\
\end{array}$ & $\begin{array}{c}0.063^{* * *} \\
(0.014) \\
9168 \\
0.063 \\
\end{array}$ & $\begin{array}{c}0.114^{* * *} \\
(0.013) \\
9168 \\
0.065 \\
\end{array}$ & $\begin{array}{c}0.005 \\
(0.012) \\
9168 \\
0.088 \\
\end{array}$ & $\begin{array}{c}-0.028^{* *} \\
(0.013) \\
7080 \\
0.567 \\
\end{array}$ & $\begin{array}{c}-0.058^{* * *} \\
(0.015) \\
9168 \\
0.264 \\
\end{array}$ \\
\hline \multicolumn{9}{|l|}{ Africa } \\
\hline $\begin{array}{l}\text { Outcome of interest } \\
\text { Intention to leave }\end{array}$ & $\begin{array}{c}0.098^{* * *} \\
(0.017) \\
3627 \\
0.140\end{array}$ & $\begin{array}{c}0.105^{* * *} \\
(0.017) \\
3627 \\
0.060\end{array}$ & $\begin{array}{c}0.140^{* * *} \\
(0.012) \\
3627 \\
0.110\end{array}$ & $\begin{array}{c}0.039^{*} \\
(0.023) \\
3627 \\
0.033\end{array}$ & $\begin{array}{c}0.119^{* * *} \\
(0.017) \\
3627 \\
0.055\end{array}$ & $\begin{array}{c}0.017 \\
(0.016) \\
3627 \\
0.107\end{array}$ & $\begin{array}{c}-0.033^{*} \\
(0.018) \\
3402 \\
0.537\end{array}$ & $\begin{array}{c}-0.024 \\
(0.016) \\
3627 \\
0.192\end{array}$ \\
\hline
\end{tabular}

Note: In all specifications, we control for gender, marital status, age, age at arrival, educational attainment (5 categories), urban status, employment status, region of origin (6 regions), region of residence in France ( 28 regions), socio-professional category ( 5 categories), presence of a child abroad and presence of a parent (mother and/or father) abroad. Additionally, we control for proficiency in French upon arrival in column (7). We lose 2088 observations in this specification for the full sample as we drop migrants from the French Overseas Territories and all migrants who were perfectly proficient in French upon arrival. Standard errors are clustered at the country of origin level. 
Table A2: 2SLS: Full sample and Africans only

\begin{tabular}{|c|c|c|c|c|c|c|c|c|c|}
\hline & & \multicolumn{5}{|c|}{ Origin country outcomes } & \multicolumn{3}{|c|}{ Host country outcomes } \\
\hline & $\begin{array}{l}\text { Outcome of } \\
\text { interest } \\
\text { (equation 2) }\end{array}$ & $\begin{array}{c}(1) \\
\text { Remit }\end{array}$ & $\begin{array}{c}(2) \\
\text { Project } \\
\text { at origin }\end{array}$ & $\begin{array}{l}\text { (3) } \\
\text { Owning } \\
\text { a house } \\
\text { at origin }\end{array}$ & $\begin{array}{c}\text { Participation } \\
\text { in elections } \\
\text { at origin }\end{array}$ & $\begin{array}{c}(5) \\
\text { Interest in } \\
\text { politics } \\
\text { outside France } \\
\end{array}$ & $\begin{array}{c}\text { (6) } \\
\text { Interest in } \\
\text { politics } \\
\text { in France } \\
\end{array}$ & $\begin{array}{c}(7) \\
\text { Improve } \\
\text { French }\end{array}$ & $\begin{array}{c}(8) \\
\text { Own house } \\
\text { in France }\end{array}$ \\
\hline & Full Sample & & & & & & & & \\
\hline Eq. 2.2 & $\begin{array}{l}\text { Outcome of interest } \\
\text { Intention to leave }\end{array}$ & $\begin{array}{c}0.486^{* * *} \\
(0.182)\end{array}$ & $\begin{array}{c}0.341^{* * * *} \\
(0.127)\end{array}$ & $\begin{array}{c}0.049 \\
(0.145)\end{array}$ & $\begin{array}{c}0.210 \\
(0.176)\end{array}$ & $\begin{array}{c}0.628^{* * *} \\
(0.129) \\
\end{array}$ & $\begin{array}{c}0.010 \\
(0.061)\end{array}$ & $\begin{array}{c}-0.279^{* * *} \\
(0.096)\end{array}$ & $\begin{array}{c}-0.489^{\text {*** }} \\
(0.119)\end{array}$ \\
\hline Eq. 2.1 & $\begin{array}{l}\text { Intention to leave } \\
\text { Exclusion restriction } \\
\text { Opinion about } \\
\text { Discrimination } \\
\text { Burial intention } \\
\text { Outside France }\end{array}$ & $\begin{array}{c}0.074^{\text {*** }} \\
(0.015)\end{array}$ & $\begin{array}{c}0.074^{* * *} \\
(0.015)\end{array}$ & $\begin{array}{c}0.074^{* * *} \\
(0.015)\end{array}$ & $\begin{array}{c}0.074^{* * *} \\
(0.015)\end{array}$ & $\begin{array}{c}0.074^{* * *} \\
(0.015)\end{array}$ & $\begin{array}{c}0.171^{* * *} \\
(0.030)\end{array}$ & $\begin{array}{c}0.148^{* * *} \\
(0.027)\end{array}$ & $\begin{array}{c}0.171^{* * *} \\
(0.030)\end{array}$ \\
\hline & $\begin{array}{c}\text { Observations } \\
\text { F-stat }\end{array}$ & $\begin{array}{l}9168 \\
25.33 \\
\end{array}$ & $\begin{array}{l}9168 \\
25.33 \\
\end{array}$ & $\begin{array}{c}9168 \\
25.33 \\
\end{array}$ & $\begin{array}{l}9168 \\
25.33 \\
\end{array}$ & $\begin{array}{l}9168 \\
25.33 \\
\end{array}$ & $\begin{array}{l}9168 \\
32.64 \\
\end{array}$ & $\begin{array}{l}7080 \\
29.16 \\
\end{array}$ & $\begin{array}{l}9168 \\
32.64 \\
\end{array}$ \\
\hline & Africa & & & & & & & & \\
\hline Eq. 2.2 & $\begin{array}{l}\text { Outcome of interest } \\
\text { Intention to leave }\end{array}$ & $\begin{array}{c}0.665^{* * *} \\
(0.174)\end{array}$ & $\begin{array}{c}0.605^{* * *} \\
(0.121)\end{array}$ & $\begin{array}{l}0.280^{* *} \\
(0.139)\end{array}$ & $\begin{array}{c}0.060 \\
(0.186)\end{array}$ & $\begin{array}{c}0.612^{* * *} \\
(0.136)\end{array}$ & $\begin{array}{c}0.002 \\
(0.107)\end{array}$ & $\begin{array}{c}-0.282^{* * *} \\
(0.094)\end{array}$ & $\begin{array}{c}-0.361^{* *} \\
(0.159)\end{array}$ \\
\hline Eq. 2.1 & $\begin{array}{l}\text { Intention to leave } \\
\text { Exclusion restriction } \\
\text { Opinion about } \\
\text { Discrimination } \\
\text { Burial intention } \\
\text { Outside France }\end{array}$ & $\begin{array}{c}0.088^{* * *} \\
(0.016)\end{array}$ & $\begin{array}{c}0.088^{* * *} \\
(0.016)\end{array}$ & $\begin{array}{c}0.088^{* * *} \\
(0.016)\end{array}$ & $\begin{array}{c}0.088^{* * *} \\
(0.016)\end{array}$ & $\begin{array}{c}0.088^{* * *} \\
(0.016)\end{array}$ & $\begin{array}{c}0.111^{* * * *} \\
(0.024)\end{array}$ & $\begin{array}{c}0.112^{* * *} \\
(0.025)\end{array}$ & $\begin{array}{c}0.111^{* * * *} \\
(0.024)\end{array}$ \\
\hline & $\begin{array}{c}\text { Observations } \\
\text { F-stat }\end{array}$ & $\begin{array}{l}3627 \\
29.17\end{array}$ & $\begin{array}{l}3627 \\
29.17\end{array}$ & $\begin{array}{l}3627 \\
29.17\end{array}$ & $\begin{array}{l}3627 \\
29.17\end{array}$ & $\begin{array}{l}3627 \\
29.17\end{array}$ & $\begin{array}{l}3627 \\
21.32\end{array}$ & $\begin{array}{l}3402 \\
19.61\end{array}$ & $\begin{array}{l}3627 \\
21.32\end{array}$ \\
\hline
\end{tabular}

Note: In all specifications, we control for gender, marital status, age, age at arrival, educational attainment ( 5 categories), urban status, employment status, region of origin (6 regions), region of residence in France (28 regions), socio-professional category (5 categories), presence of a child abroad and presence of a parent (mother and/or father) abroad. Additionally, we control for proficiency in French upon arrival in column (7). We lose 2088 observations in this specification for the full sample as we drop migrants from the French Overseas Territories as they were all perfectly proficient in French upon arrival. Standard errors are clustered at the country of origin level. 


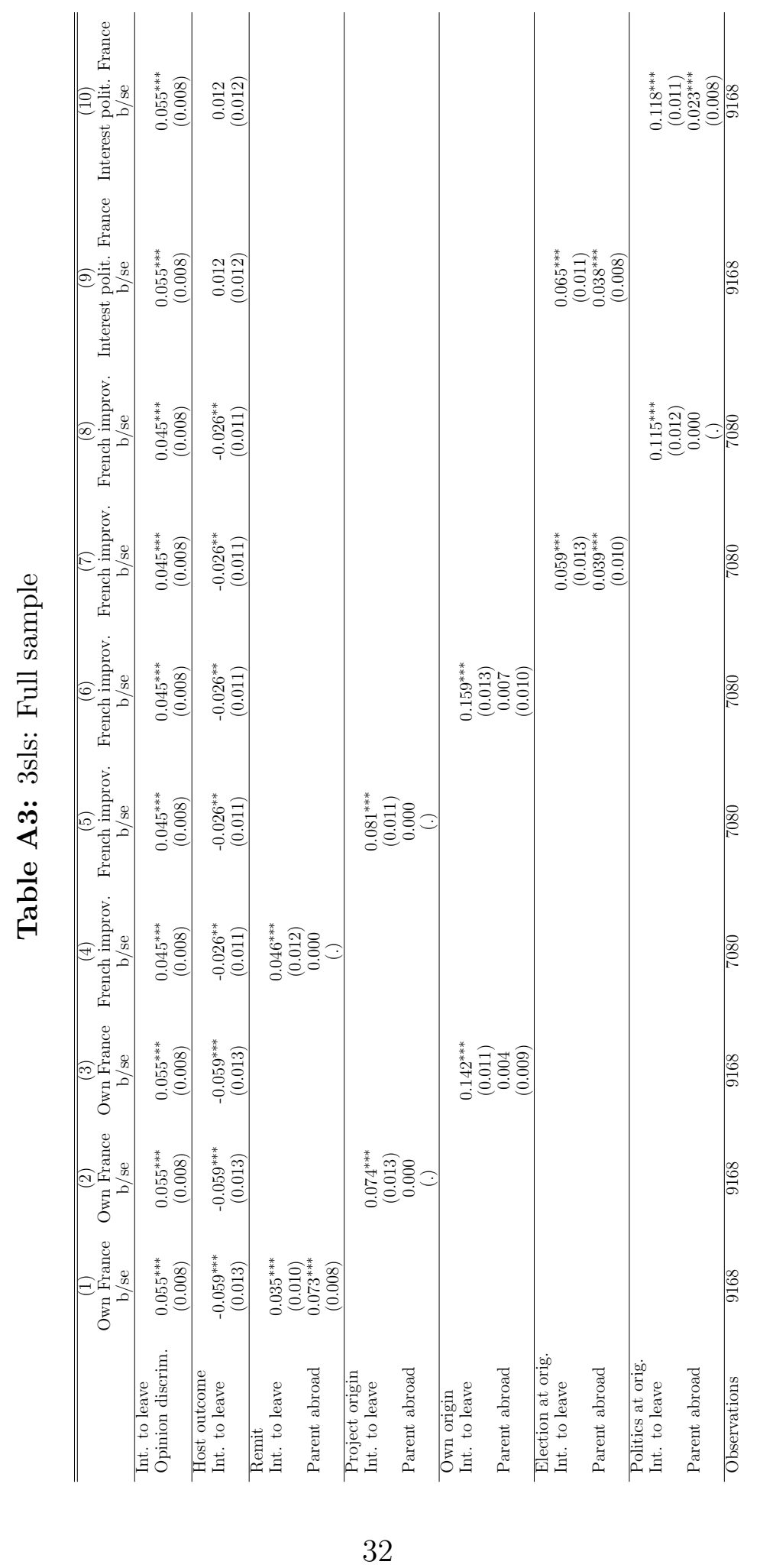




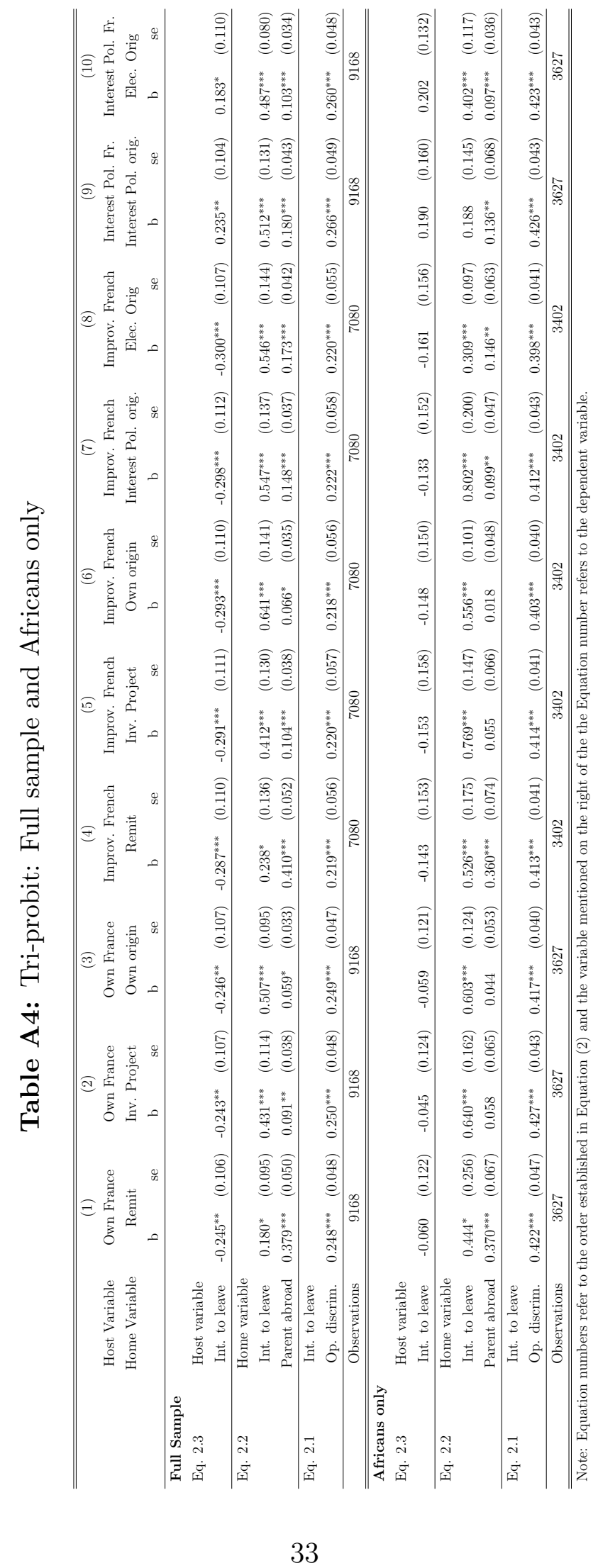


Table A5: Home-Home outcomes

\begin{tabular}{|c|c|c|c|}
\hline & $\begin{array}{c}(1) \\
\text { Remit } \\
\text { b/se }\end{array}$ & $\begin{array}{c}(2) \\
\text { Remit } \\
\mathrm{b} / \mathrm{se}\end{array}$ & $\begin{array}{c}(3) \\
\text { Project origin } \\
\mathrm{b} / \mathrm{se}\end{array}$ \\
\hline Int. to leave & $\begin{array}{c}0.181 \\
(0.142)\end{array}$ & $\begin{array}{c}0.197 \\
(0.149)\end{array}$ & $\begin{array}{c}0.380^{* * *} \\
(0.066)\end{array}$ \\
\hline $\begin{array}{l}\text { Project origin } \\
\text { Int. to leave }\end{array}$ & $\begin{array}{c}0.283^{* * *} \\
(0.025)\end{array}$ & & \\
\hline $\begin{array}{l}\text { Own origin } \\
\text { Int. to leave }\end{array}$ & & $\begin{array}{c}0.449^{* * *} \\
(0.134)\end{array}$ & $\begin{array}{c}0.468^{* * *} \\
(0.135)\end{array}$ \\
\hline $\begin{array}{l}\text { Observations } \\
R h o_{12}\end{array}$ & $\begin{array}{c}9168 \\
0.223^{* * *} \\
\end{array}$ & $\begin{array}{c}9168 \\
0.180^{* * *}\end{array}$ & $\begin{array}{c}9168 \\
0.228^{* * *}\end{array}$ \\
\hline
\end{tabular}

Note: This table provides results for a trivariate probit model where the two equations with home outcomes as dependent variable have intention to leave as a control and the third equation has intention to leave as a dependent variable. 
Table A6: Bi-probit: Intention to leave "Yes" and "Maybe"

\begin{tabular}{|c|c|c|c|c|c|c|c|c|c|}
\hline & & \multicolumn{5}{|c|}{ Origin country outcomes } & \multicolumn{3}{|c|}{ Host country outcomes } \\
\hline & $\begin{array}{l}\text { Outcome of } \\
\text { interest } \\
\text { (equation 2) }\end{array}$ & $\begin{array}{c}(1) \\
\text { Remit }\end{array}$ & $\begin{array}{c}(2) \\
\text { Project } \\
\text { at origin }\end{array}$ & $\begin{array}{c}(3) \\
\text { Owning } \\
\text { a house } \\
\text { at origin }\end{array}$ & $\begin{array}{c}(4) \\
\text { Participation } \\
\text { in elections } \\
\text { at origin }\end{array}$ & $\begin{array}{c}(5) \\
\text { Interest in } \\
\text { politics } \\
\text { outside France }\end{array}$ & $\begin{array}{c}\text { (6) } \\
\text { Interest in } \\
\text { politics } \\
\text { in France } \\
\end{array}$ & $\begin{array}{c}(7) \\
\text { Improve } \\
\text { French }\end{array}$ & $\begin{array}{c}(8) \\
\text { Own house } \\
\text { in France }\end{array}$ \\
\hline & Full Sample & & & & & & & & \\
\hline Eq. 2.2 & $\begin{array}{l}\text { Outcome of interest } \\
\text { Intention to leave }\end{array}$ & $\begin{array}{c}0.605^{* * *} \\
(0.198)\end{array}$ & $\begin{array}{l}1.193^{* * *} \\
(0.184)\end{array}$ & $\begin{array}{c}0.180 \\
(0.352)\end{array}$ & $\begin{array}{c}1.458^{* * *} \\
(0.106)\end{array}$ & $\begin{array}{c}1.158^{* * *} \\
(0.121)\end{array}$ & $\begin{array}{l}-0.171 \\
(0.179)\end{array}$ & $\begin{array}{c}-1.028^{* * *} \\
(0.179)\end{array}$ & $\begin{array}{c}-0.754^{* * *} \\
(0.144)\end{array}$ \\
\hline Eq. 2.1 & $\begin{array}{l}\text { Intention to leave } \\
\text { Exclusion restriction } \\
\text { Opinion about } \\
\text { Discrimination } \\
\text { Burial intention } \\
\text { outside France } \\
\text { Observations }\end{array}$ & $\begin{array}{c}0.196^{* * *} \\
(0.036)\end{array}$ & $\begin{array}{c}0.198^{* * *} \\
(0.036)\end{array}$ & $\begin{array}{c}0.193^{* * *} \\
(0.037)\end{array}$ & $\begin{array}{c}0.176^{* * *} \\
(0.035)\end{array}$ & $\begin{array}{c}0.212^{* * * *} \\
(0.032)\end{array}$ & $\begin{array}{c}0.577^{* * *} \\
(0.048) \\
9168\end{array}$ & $\begin{array}{c}0.567^{* * *} \\
(0.054) \\
7080\end{array}$ & $\begin{array}{c}0.582^{* * *} \\
(0.048) \\
9168\end{array}$ \\
\hline
\end{tabular}

Table A7: Bi-probit: Plan to leave vs. Intention

\begin{tabular}{|c|c|c|c|c|c|c|c|c|c|}
\hline & & \multicolumn{5}{|c|}{ Origin country outcomes } & \multicolumn{3}{|c|}{ Host country outcomes } \\
\hline & $\begin{array}{l}\text { Outcome of } \\
\text { interest } \\
\text { (equation 2) }\end{array}$ & $\begin{array}{c}(1) \\
\text { Remit }\end{array}$ & $\begin{array}{l}(2) \\
\text { Project } \\
\text { at origin }\end{array}$ & $\begin{array}{c}(3) \\
\text { Owning } \\
\text { a house } \\
\text { at origin }\end{array}$ & $\begin{array}{c}\text { (4) } \\
\text { Participation } \\
\text { in elections } \\
\text { at origin }\end{array}$ & $\begin{array}{c}(5) \\
\text { Interest in } \\
\text { politics } \\
\text { outside France }\end{array}$ & $\begin{array}{c}\text { (6) } \\
\text { Interest in } \\
\text { politics } \\
\text { in France } \\
\end{array}$ & $\begin{array}{l}(7) \\
\text { Improve } \\
\text { French }\end{array}$ & $\begin{array}{l}\quad(8) \\
\text { Own house } \\
\text { in France }\end{array}$ \\
\hline & Full Sample & & & & & & & & \\
\hline Eq. 2.2 & $\begin{array}{l}\text { Outcome of interest } \\
\text { Intention to leave }\end{array}$ & $\begin{array}{c}-0.461 \\
(0.660)\end{array}$ & $\begin{array}{l}1.399^{*} \\
(0.734)\end{array}$ & $\begin{array}{c}0.842 \\
(1.136)\end{array}$ & & & $\begin{array}{l}1.093^{*} \\
(0.656)\end{array}$ & $\begin{array}{l}-1.164 \\
(0.772)\end{array}$ & $\begin{array}{c}-1.532^{* * *} \\
(0.243)\end{array}$ \\
\hline Eq. 2.1 & $\begin{array}{l}\text { Intention to leave } \\
\text { Exclusion restriction } \\
\text { Opinion about } \\
\text { Discrimination } \\
\text { Burial intention } \\
\text { outside France } \\
\text { Observations }\end{array}$ & $\begin{array}{c}0.119 \\
(0.075)\end{array}$ & $\begin{array}{l}0.149^{* *} \\
(0.070)\end{array}$ & $\begin{array}{c}0.130^{*} \\
(0.075)\end{array}$ & & & $\begin{array}{c}0.265^{* * *} \\
(0.096) \\
3720\end{array}$ & $\begin{array}{c}0.261^{\text {** }} \\
(0.127) \\
2682\end{array}$ & $\begin{array}{c}0.383^{* * *} \\
(0.074) \\
3720\end{array}$ \\
\hline
\end{tabular}


Table A8: Bi-probit: remigration definitions

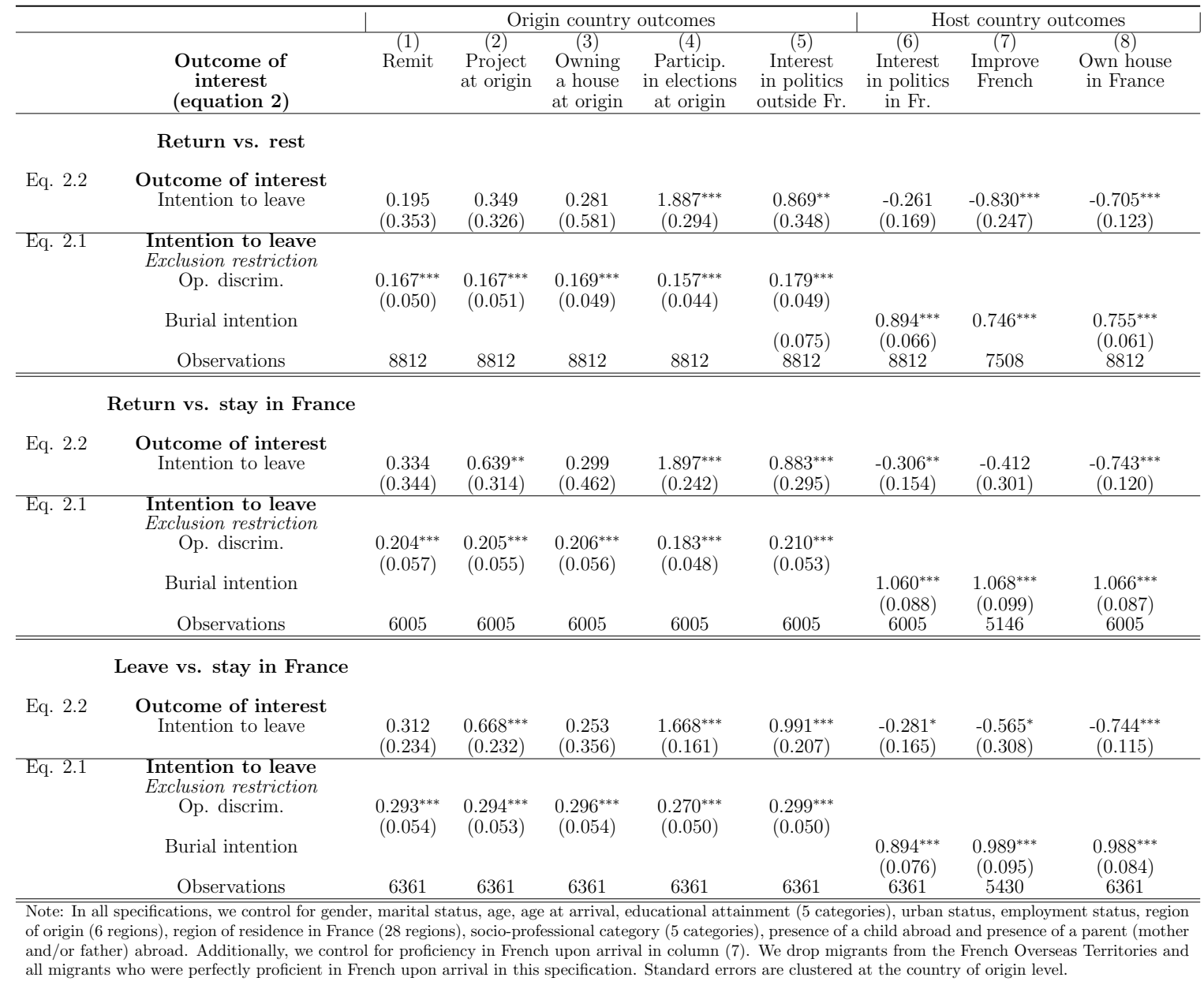


Table A9: Bi-probit: Sub-sample with income

\begin{tabular}{|c|c|c|c|c|c|c|c|c|c|}
\hline & & \multicolumn{5}{|c|}{ Origin country outcomes } & \multicolumn{3}{|c|}{ Host country outcomes } \\
\hline & $\begin{array}{l}\text { Outcome of } \\
\text { interest } \\
\text { (equation 2) }\end{array}$ & $\begin{array}{c}(1) \\
\text { Remit }\end{array}$ & $\begin{array}{c}(2) \\
\text { Project } \\
\text { at origin }\end{array}$ & $\begin{array}{l}(3) \\
\text { Owning } \\
\text { a house } \\
\text { at origin }\end{array}$ & $\begin{array}{l}\text { (4) } \\
\text { Participation } \\
\text { in elections } \\
\text { at origin } \\
\end{array}$ & $\begin{array}{c}(5) \\
\text { Interest in } \\
\text { politics } \\
\text { outside France } \\
\end{array}$ & $\begin{array}{l}\text { (6) } \\
\text { Interest in } \\
\text { politics } \\
\text { in France } \\
\end{array}$ & $\begin{array}{l}\text { (7) } \\
\text { Improve } \\
\text { French }\end{array}$ & $\begin{array}{l}\text { (8) } \\
\text { Own house } \\
\text { in France }\end{array}$ \\
\hline Eq. 2.2 & $\begin{array}{l}\text { Full Sample (baseline) } \\
\text { Outcome of interest } \\
\text { Intention to leave }\end{array}$ & $\begin{array}{c}0.156 \\
(0.322) \\
\end{array}$ & $\begin{array}{c}0.452^{*} \\
(0.248) \\
\end{array}$ & $\begin{array}{c}0.209 \\
(0.514) \\
\end{array}$ & $\begin{array}{c}1.697^{* * *} \\
(0.192)\end{array}$ & $\begin{array}{c}0.983^{* * *} \\
(0.209) \\
\end{array}$ & $\begin{array}{c}-0.126 \\
(0.183) \\
\end{array}$ & $\begin{array}{c}-0.898^{* * *} \\
(0.218) \\
\end{array}$ & $\begin{array}{c}-0.704^{* * *} \\
(0.164) \\
\end{array}$ \\
\hline Eq. 2.1 & $\begin{array}{c}\text { Intention to leave } \\
\text { Exclusion restriction } \\
\text { Opinion about } \\
\text { Discrimination } \\
\text { Burial intention } \\
\text { Outside France } \\
\text { Observations }\end{array}$ & $\begin{array}{c}0.260^{* * *} \\
(0.051)\end{array}$ & $\begin{array}{c}0.262^{\text {**** }} \\
(0.050)\end{array}$ & $\begin{array}{c}0.264^{* * *} \\
(0.052)\end{array}$ & $\begin{array}{c}0.244^{* * *} \\
(0.047)\end{array}$ & $\begin{array}{c}0.273^{* * *} \\
(0.048)\end{array}$ & $\begin{array}{c}\begin{array}{c}0.740^{* * * *} \\
(0.061)\end{array} \\
8392\end{array}$ & $\begin{array}{c}0.728^{* * *} \\
(0.077)\end{array}$ & $\begin{array}{c}0.744^{* * *} \\
(0.059)\end{array}$ \\
\hline
\end{tabular}

Table A10: Bi-probit: excluding individuals aged 16 or less at arrival

\begin{tabular}{|c|c|c|c|c|c|c|c|c|c|}
\hline & & \multicolumn{5}{|c|}{ Origin country outcomes } & \multicolumn{3}{|c|}{ Host country outcomes } \\
\hline & $\begin{array}{c}\text { Outcome of } \\
\text { interest } \\
\text { (equation 2) }\end{array}$ & $\begin{array}{c}(1) \\
\text { Remit }\end{array}$ & $\begin{array}{c}(2) \\
\text { Project } \\
\text { at origin }\end{array}$ & $\begin{array}{l}(3) \\
\text { Owning } \\
\text { a house } \\
\text { at origin } \\
\end{array}$ & $\begin{array}{c}(4) \\
\text { Participation } \\
\text { in elections } \\
\text { at origin }\end{array}$ & $\begin{array}{c}(5) \\
\text { Interest in } \\
\text { politics } \\
\text { outside France } \\
\end{array}$ & $\begin{array}{c}\text { (6) } \\
\text { Interest in } \\
\text { politics } \\
\text { in France } \\
\end{array}$ & $\begin{array}{c}(7) \\
\text { Improve } \\
\text { French }\end{array}$ & $\begin{array}{l}\text { (8) } \\
\text { Own house } \\
\text { in France }\end{array}$ \\
\hline Eq. 2.2 & $\begin{array}{c}\text { Full Sample } \\
\text { Outcome of interest } \\
\text { Intention to leave }\end{array}$ & $\begin{array}{c}0.332 \\
(0.306)\end{array}$ & $\begin{array}{c}0.610^{* *} \\
(0.277)\end{array}$ & $\begin{array}{c}0.219 \\
(0.611)\end{array}$ & $\begin{array}{c}1.451^{* * *} \\
(0.236)\end{array}$ & $\begin{array}{c}0.963^{* * *} \\
(0.247)\end{array}$ & $\begin{array}{c}-0.407^{* *} \\
(0.175)\end{array}$ & $\begin{array}{c}-0.797^{* * *} \\
(0.275)\end{array}$ & $\begin{array}{c}-0.922^{* * *} \\
(0.125)\end{array}$ \\
\hline Eq. 2.1 & $\begin{array}{c}\text { Intention to leave } \\
\text { Exclusion restriction } \\
\text { Opinion about } \\
\text { Discrimination } \\
\text { Burial intention } \\
\text { Outside France } \\
\text { Observations }\end{array}$ & $\begin{array}{c}0.287^{* * *} \\
(0.043)\end{array}$ & $\begin{array}{c}0.287^{* * *} \\
(0.042)\end{array}$ & $\begin{array}{c}0.287^{* * *} \\
(0.044)\end{array}$ & $\begin{array}{c}0.271^{* * *} \\
(0.046)\end{array}$ & $\begin{array}{c}0.295^{* * *} \\
(0.040)\end{array}$ & $\begin{array}{c}\begin{array}{c}0.780^{\text {*** }} \\
(0.070)\end{array} \\
6365\end{array}$ & $\begin{array}{c}0.787^{\text {*** }} \\
(0.096)\end{array}$ & $\begin{array}{c}0.786^{* * *} \\
(0.066)\end{array}$ \\
\hline & Observations & 6365 & 6365 & 6365 & 6365 & 6365 & 6365 & 4752 & 6365 \\
\hline
\end{tabular}


Table A11: Bi-probit: Sample composition (exclude current students)

\begin{tabular}{|c|c|c|c|c|c|c|c|c|c|}
\hline \multirow{2}{*}{\multicolumn{2}{|c|}{$\begin{array}{l}\text { Outcome of } \\
\text { interest } \\
\text { (equation 2) }\end{array}$}} & \multicolumn{5}{|c|}{ Origin country outcomes } & \multicolumn{3}{|c|}{ Host country outcomes } \\
\hline & & $\begin{array}{c}\text { (1) } \\
\text { Remit }\end{array}$ & $\begin{array}{c}(2) \\
\text { Project } \\
\text { at origin }\end{array}$ & $\begin{array}{c}(3) \\
\text { Owning } \\
\text { a house } \\
\text { at origin }\end{array}$ & $\begin{array}{c}(4) \\
\text { Participation } \\
\text { in elections } \\
\text { at origin }\end{array}$ & $\begin{array}{c}(5) \\
\text { Interest in } \\
\text { politics } \\
\text { outside France }\end{array}$ & $\begin{array}{c}\text { (6) } \\
\text { Interest in } \\
\text { politics } \\
\text { in France }\end{array}$ & $\begin{array}{c}(7) \\
\text { Improve } \\
\text { French }\end{array}$ & $\begin{array}{l}\text { (8) } \\
\text { Own house } \\
\text { in France }\end{array}$ \\
\hline & Full Sample & & & & & & & & \\
\hline Eq. 2.2 & $\begin{array}{l}\text { Outcome of interest } \\
\text { Intention to leave }\end{array}$ & $\begin{array}{c}0.222 \\
(0.256)\end{array}$ & $\begin{array}{c}0.626^{* * * *} \\
(0.217)\end{array}$ & $\begin{array}{c}0.381 \\
(0.451)\end{array}$ & $\begin{array}{c}1.644^{* * * *} \\
(0.203)\end{array}$ & $\begin{array}{c}1.074^{* * *} \\
(0.204)\end{array}$ & $\begin{array}{c}-0.214 \\
(0.184)\end{array}$ & $\begin{array}{c}-0.908^{* * *} \\
(0.225)\end{array}$ & $\begin{array}{c}-0.717^{* * *} \\
(0.143)\end{array}$ \\
\hline Eq. 2.1 & $\begin{array}{l}\text { Intention to leave } \\
\text { Exclusion restriction } \\
\text { Op. discrim. } \\
\text { Burial intention } \\
\text { Outside France } \\
\text { Observations }\end{array}$ & $\begin{array}{c}0.251^{* * *} \\
(0.050)\end{array}$ & $\begin{array}{c}0.255^{* * *} \\
(0.050)\end{array}$ & $\begin{array}{c}0.252^{* * *} \\
(0.051)\end{array}$ & $\begin{array}{c}0.235^{* * *} \\
(0.046)\end{array}$ & $\begin{array}{c}0.264^{* * *} \\
(0.046)\end{array}$ & $\begin{array}{c}0.744^{* * *} \\
(0.064) \\
8847\end{array}$ & $\begin{array}{c}0.732^{* * *} \\
(0.084) \\
6865\end{array}$ & $\begin{array}{c}0.750^{* * *} \\
(0.062) \\
8847\end{array}$ \\
\hline
\end{tabular}

Table A12: Bi-probit: excluding individuals born in DOM

\begin{tabular}{|c|c|c|c|c|c|c|c|c|c|}
\hline & & \multicolumn{5}{|c|}{ Origin country outcomes } & \multicolumn{3}{|c|}{ Host country outcomes } \\
\hline & $\begin{array}{l}\text { Outcome of } \\
\text { interest } \\
\text { (equation 2) }\end{array}$ & $\begin{array}{c}(1) \\
\text { Remit }\end{array}$ & $\begin{array}{c}(2) \\
\text { Project } \\
\text { at origin }\end{array}$ & $\begin{array}{l}(3) \\
\text { Owning } \\
\text { a house } \\
\text { at origin }\end{array}$ & $\begin{array}{c}\text { (4) } \\
\text { Participation } \\
\text { in elections } \\
\text { at origin }\end{array}$ & $\begin{array}{c}\text { (5) } \\
\text { Interest in } \\
\text { politics } \\
\text { outside France } \\
\end{array}$ & $\begin{array}{c}\text { (6) } \\
\text { Interest in } \\
\text { politics } \\
\text { in France }\end{array}$ & $\begin{array}{l}\text { (7) } \\
\text { Improve } \\
\text { French }\end{array}$ & $\begin{array}{l}\text { (8) } \\
\text { Own house } \\
\text { in France }\end{array}$ \\
\hline Eq. 2.2 & $\begin{array}{l}\text { Full Sample } \\
\text { Outcome of interest } \\
\text { Intention to leave }\end{array}$ & $\begin{array}{c}0.268 \\
(0.279)\end{array}$ & $\begin{array}{c}0.424 \\
(0.271)\end{array}$ & $\begin{array}{c}0.177 \\
(0.532)\end{array}$ & $\begin{array}{c}1.673^{* * *} \\
(0.202)\end{array}$ & $\begin{array}{c}1.094^{* * *} \\
(0.200)\end{array}$ & $\begin{array}{l}-0.317 \\
(0.203)\end{array}$ & $\begin{array}{c}-0.934^{* * *} \\
(0.203)\end{array}$ & $\begin{array}{c}-0.733^{* * *} \\
(0.150)\end{array}$ \\
\hline Eq. 2.1 & $\begin{array}{l}\text { Intention to leave } \\
\text { Exclusion restriction } \\
\text { Opinion about } \\
\text { Discrimination } \\
\text { Burial intention } \\
\text { Outside France } \\
\text { Observations }\end{array}$ & $\begin{array}{c}0.259^{* * *} \\
(0.053)\end{array}$ & $\begin{array}{c}0.259^{* * *} \\
(0.055)\end{array}$ & $\begin{array}{c}0.260^{* * *} \\
(0.053)\end{array}$ & $\begin{array}{c}0.243^{\text {*** }} \\
(0.048)\end{array}$ & $\begin{array}{c}0.272^{\text {*** }} \\
(0.049)\end{array}$ & $\begin{array}{c}0.706^{* * *} \\
(0.070)\end{array}$ & $\begin{array}{c}0.726^{* * *} \\
(0.083)\end{array}$ & $\begin{array}{c}\begin{array}{c}0.715^{\text {**** }} \\
(0.068)\end{array} \\
8456\end{array}$ \\
\hline
\end{tabular}


Table A13: Bi-probit: Double instrument

\begin{tabular}{|c|c|c|c|c|c|c|c|c|c|}
\hline & & \multicolumn{5}{|c|}{ Origin country outcomes } & \multicolumn{3}{|c|}{ Host country outcomes } \\
\hline & $\begin{array}{c}\text { Outcome of } \\
\text { interest } \\
\text { (equation 2) }\end{array}$ & $\begin{array}{c}(1) \\
\text { Remit }\end{array}$ & $\begin{array}{c}(2) \\
\text { Project } \\
\text { at origin }\end{array}$ & $\begin{array}{l}(3) \\
\text { Owning } \\
\text { a house } \\
\text { at origin }\end{array}$ & $\begin{array}{l}\text { Participation } \\
\text { in elections } \\
\text { at origin }\end{array}$ & $\begin{array}{c}(5) \\
\text { Interest in } \\
\text { politics } \\
\text { outside France } \\
\end{array}$ & $\begin{array}{l}\text { (6) } \\
\text { Interest in } \\
\text { politics } \\
\text { in France } \\
\end{array}$ & $\begin{array}{l}\text { (7) } \\
\text { Improve } \\
\text { French }\end{array}$ & $\begin{array}{l}\text { (8) } \\
\text { Own house } \\
\text { in France }\end{array}$ \\
\hline Eq. 2.2 & $\begin{array}{l}\text { Full Sample (baseline) } \\
\text { Outcome of interest } \\
\text { Intention to leave }\end{array}$ & $\begin{array}{c}0.091 \\
(0.331) \\
\end{array}$ & $\begin{array}{c}0.384^{*} \\
(0.231)\end{array}$ & $\begin{array}{c}1.126^{* * *} \\
(0.258) \\
\end{array}$ & $\begin{array}{c}1.626^{* * *} \\
(0.185) \\
\end{array}$ & $\begin{array}{c}1.077^{* * *} \\
(0.151) \\
\end{array}$ & $\begin{array}{l}-0.100 \\
(0.195) \\
\end{array}$ & $\begin{array}{c}-0.904^{* * *} \\
(0.229) \\
\end{array}$ & $\begin{array}{c}-0.736^{* * *} \\
(0.162) \\
\end{array}$ \\
\hline Eq. 2.1 & $\begin{array}{l}\text { Intention to leave } \\
\text { Exclusion restriction } \\
\text { Opinion about } \\
\text { Discrimination } \\
\text { Burial intention } \\
\text { Outside France } \\
\text { Share origin }\end{array}$ & $\begin{array}{c}3.122^{* * *} \\
(0.205) \\
9168\end{array}$ & $\begin{array}{c}3.118^{* * *} \\
(0.205) \\
9168\end{array}$ & $\begin{array}{c}3.297^{* * *} \\
(0.235) \\
9168\end{array}$ & $\begin{array}{c}3.096^{* * *} \\
(0.270)\end{array}$ & $\begin{array}{c}3.174^{* * *} \\
(0.206) \\
9168\end{array}$ & $\begin{array}{c}0.712^{* * *} \\
(0.064) \\
2.670^{* * *} \\
(0.210) \\
9168\end{array}$ & $\begin{array}{c}0.699^{* * * *} \\
(0.083) \\
2.831^{* * *} \\
(0.265) \\
7080\end{array}$ & $\begin{array}{c}0.721^{* * *} \\
(0.062) \\
2.620^{* * *} \\
(0.194) \\
9168\end{array}$ \\
\hline
\end{tabular}

